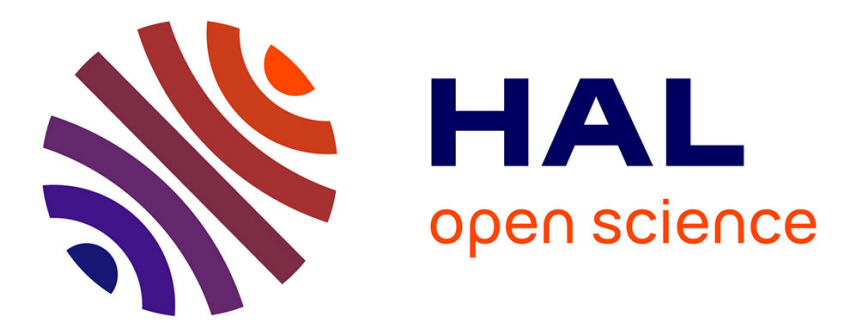

\title{
Sulfur Isotope Evidence for a Geochemical Zonation of the Samoan Mantle Plume
}

James W. Dottin, Jabrane Labidi, Matthew G. Jackson, James Farquhar

\section{To cite this version:}

James W. Dottin, Jabrane Labidi, Matthew G. Jackson, James Farquhar. Sulfur Isotope Evidence for a Geochemical Zonation of the Samoan Mantle Plume. Geochemistry, Geophysics, Geosystems, 2021, 22, pp.1510-1517. 10.1029/2021GC009816 . insu-03590046

\section{HAL Id: insu-03590046 https://hal-insu.archives-ouvertes.fr/insu-03590046}

Submitted on 26 Feb 2022

HAL is a multi-disciplinary open access archive for the deposit and dissemination of scientific research documents, whether they are published or not. The documents may come from teaching and research institutions in France or abroad, or from public or private research centers.
L'archive ouverte pluridisciplinaire HAL, est destinée au dépôt et à la diffusion de documents scientifiques de niveau recherche, publiés ou non, émanant des établissements d'enseignement et de recherche français ou étrangers, des laboratoires publics ou privés. 


\section{Geochemistry, Geophysics, Geosystems}

\author{
RESEARCH ARTICLE \\ 10.1029/2021GC009816 \\ Key Points: \\ - Basalts from Samoan volcanoes \\ preserve heterogeneous sulfur \\ isotope signatures \\ - We observe unique S-isotope \\ compositions associated with \\ distinct groups of Samoan volcanoes \\ - Sulfur isotope variability is \\ associated with multiple distinct \\ recycled components
}

Supporting Information:

Supporting Information may be found in the online version of this article.

Correspondence to:

J. W. Dottin III,

jdottin@umd.edu

Citation:

Dottin III, J. W., Labidi, J., Jackson, M. G., \& Farquhar, J. (2021). Sulfur isotope evidence for a geochemical zonation of the Samoan mantle plume. Geochemistry, Geophysics, Geosystems, 22, e2021GC009816. https://doi. org/10.1029/2021GC009816

Received 2 APR 2021 Accepted 1 JUN 2021
(C) 2021. American Geophysical Union. All Rights Reserved.

\section{Sulfur Isotope Evidence for a Geochemical Zonation of the Samoan Mantle Plume}

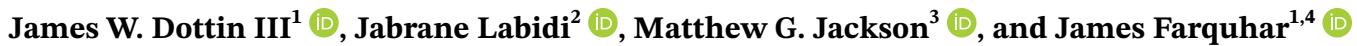 \\ ${ }^{1}$ Department of Geology, University of Maryland, College Park, MD, USA, ${ }^{2}$ Universite de Paris Institut de Physique du \\ Globe de Paris, CNRS, Paris, France, ${ }^{3}$ Department of Earth Science, University of California, Santa Barbara, CA, USA, \\ ${ }^{4}$ Earth System Science Interdisciplinary Center, University of Maryland, College Park, MD, USA
}

\begin{abstract}
Basalts from the Samoan volcanoes sample contributions from all of the classical mantle endmembers, including extreme EM II and high ${ }^{3} \mathrm{He} /{ }^{4} \mathrm{He}$ components, as well as dilute contributions from the HIMU, EM I, and DM components. Here, we present multiple sulfur isotope data on sulfide extracted from subaerial and submarine whole rocks $(N=16)$ associated with several Samoan volcanoesVailulu'u, Malumalu, Malutut, Upolu, Savai'i, and Tutuila - that sample the full range of geochemical heterogeneity at Samoa and upon exhaustive compilation of S-isotope data for Samoan lavas, allow for an assessment of the S-isotope compositions associated with the different mantle components sampled by the Samoan hotspot. We observe variable $S$ concentrations $(10-1,000 \mathrm{ppm})$ and $\delta^{34} \mathrm{~S}$ values $(-0.29 \% \mathrm{\pm}$ 0.30 to $+4.84 \%$ $\pm 0.30,2 \sigma)$. The observed variable $S$ concentrations are likely due to sulfide segregation and degassing processes. The range in $\delta^{34} \mathrm{~S}$ reflects mixing between the mantle origin and recycled components, and isotope fractionations associated with degassing. The majority of samples reveal $\Delta^{33} \mathrm{~S}$ within uncertainty of $\Delta^{33} S=0 \% \pm \pm 0.008$. Important exceptions to this observation include: (a) a negative $\Delta^{33} \mathrm{~S}(-0.018 \% \circ \pm 0.008,2 \sigma)$ from a rejuvenated basalt on Upolu island (associated with a diluted EM I component) and (b) previously documented small (but resolvable) $\Delta^{33} S$ values (up to $+0.027 \pm 0.016$ ) associated with the Vai Trend (associated with a diluted HIMU component). The variability we observed in $\Delta^{33} \mathrm{~S}$ is interpreted to reflect contributions of sulfur of different origins and likely multiple crustal protoliths. $\Delta^{36} \mathrm{~S}$ versus $\Delta^{33} \mathrm{~S}$ relationships suggest all recycled $\mathrm{S}$ is of post-Archean origin.
\end{abstract}

Plain Language Summary Samoa is a group of volcanoes as islands and seamounts that reside in the south Pacific Ocean. This group of volcanoes are unique in that they erupt material from the deep mantle that was once at the surface, suggesting large scale crustal recycling was at play. Furthermore, distinct groupings of volcanoes and seamounts appear to erupt distinct recycled components. However, the nature and relative age of these components are not well understood. We use sulfur isotopes to gain insights into the materials erupted at Samoa. We provide evidence that the mantle plume beneath Samoa is geochemically zoned, as S-isotopes are distinct at different groups of islands. We also argue that the identified recycled materials are best linked to Proterozoic sulfur and in some cases may represent recycled S reservoirs that are distributed among multiple Pacific Ocean island basalts.

\section{Introduction}

Ocean island basalts (OIB) are volcanic rocks associated with hotspots erupted at intraplate locations in the world's ocean basins. Through the geochemical characterization of OIB and mid-ocean ridge basalts (MORB) with long lived-radiogenic isotopes of strontium $(\mathrm{Sr})$, neodymium $(\mathrm{Nd})$, and lead $(\mathrm{Pb})$, the mantle can be characterized into four chemically distinct geochemical components: Depleted MORB Mantle (DMM), Enriched Mantle 1 (EM I), Enriched Mantle 2 (EM II), and HIMU (high $\mu={ }^{238} \mathrm{U} /{ }^{204} \mathrm{~Pb}$ ) (Zindler \& Hart, 1986). These components represent mantle depleted by melt extraction (DMM), and components that formed from recycling of continental materials (EM) and oceanic crust (HIMU) (e.g. Hofmann, 1997; Hofmann \& White, 1982; Jackson et al., 2007a; White \& Hoffman, 1982; Workman et al., 2008; Zindler \& Hart, 1986).

The Samoan islands and seamounts, collectively called Samoa, are located in the south Pacific Ocean, positioned just north of the northern terminus of the Tonga trench. Samoa is the type locality for the EM II mantle signature, which hosts the highest ${ }^{87} \mathrm{Sr} /{ }^{86} \mathrm{Sr}$ in global OIB-interpreted to reflect ancient recycled 
terrigenous sediment of submarine origin (Adams et al., 2021a; Adams et al., 2021b; Workman et al., 2008) or recycled continental crustal materials (e.g. Jackson et al., 2007a). A complication is that various islands within Samoa exhibit geochemically distinct trends in ${ }^{208} \mathrm{~Pb}^{/ 204} \mathrm{~Pb}$ versus ${ }^{206} \mathrm{~Pb} /{ }^{204} \mathrm{~Pb}$ space. This indicates the presence of dilute contributions from other mantle endmembers including HIMU (recycled oceanic crust) and DM (Depleted Mantle) (Jackson et al., 2014). Some of the islands at Samoa have also experienced rejuvenated volcanism (volcanism after a period of quiescence), erupting geochemically distinct material with dilute EM I type compositions (Jackson et al., 2014).

In addition to hosting recycled components, Samoa also exhibits a contribution from a deep primordial component. This primordial material was initially identified by high ${ }^{3} \mathrm{He} /{ }^{4} \mathrm{He}$ (Farley et al., 1992; Jackson et al., 2007b) and later shown to be associated with negative $\mu^{182} \mathrm{~W}$ (Mundl et al., 2017; Mundl-Petermeier et al., 2020), linking the reservoir to possible chemical equilibration between the core and the deep mantle. $\mathrm{In} \mathrm{Pb}$-isotope space, the various geochemical trends identified in Samoan lavas converge on $\mathrm{Pb}$-isotope compositions associated with a high ${ }^{3} \mathrm{He} /{ }^{4} \mathrm{He}$ (Jackson et al., 2014) component, termed FOZO (Focus Zone; Hart et al., 1992), PHEM (Primitive Helium Mantle; Farley et al. 1992) or C (Common; Hanan \& Graham, 1996). The convergence on this component provides evidence for mixing between primordial mantle and multiple recycled components in the Samoan plume.

Sulfur isotope compositions of OIB can provide unique constraints on the origin of mantle components and have been used to trace and identify various sources of sulfur that have been recycled into the mantle. The ability to identify recycled sulfur protoliths is rooted in the clear dichotomy in $\Delta^{33} \mathrm{~S}$ measurements among Archean versus Post-Archean sediments, where Archean sediments readily host large $\Delta^{33} \mathrm{~S}$ variations versus post-Archean materials with typically $\Delta^{33} \mathrm{~S}=0 \%$ o (e.g., Johnston, 2011), as well as clear differences in the $\delta^{34} \mathrm{~S}$ composition of various crustal components (e.g. Lower Ocean Crust $=+3 \%$ in $\delta^{34} \mathrm{~S}$, [e.g., Alt, 1995]). At Mangaia, the type locality for the HIMU mantle reservoir, work by Cabral et al. (2013) identified anomalous S-isotope compositions in the form of negative $\delta^{34} \mathrm{~S}$ and negative $\Delta^{33} \mathrm{~S}$ that are argued to reflect the recycling of Archean S stored in oceanic crust. Dottin et al. (2020a) suggested that Mangaia basalts also preserve slightly positive $\Delta^{33} \mathrm{~S}$ that is linked to recycled post-Archean sulfur. At Pitcairn, an EM I locality, Delavault et al. (2016) observed negative $\delta^{34} \mathrm{~S}$ and negative $\Delta^{33} \mathrm{~S}$ in individual sulfide grains and argued that the compositions originate from recycled Archean S. Note, that recycled Archean S is not widely observed, as other localities showing EM I (e.g. Discovery, Labidi et al., 2013) and mild HIMU compositions (e.g. Canary Islands, Beaudry et al., 2018) do not exhibit anomalous $\Delta^{33}$ S. Basalts with EM II signatures at Samoa were previously shown to host positive $\delta^{34} \mathrm{~S}$ but $\Delta^{33} \mathrm{~S}$ that averages within uncertainty of the origin $\left(\Delta^{33} \mathrm{~S}=0\right)$ (Labidi et al., 2015), which is argued to reflect the recycling of sediments of Proterozoic age. Recent work by Dottin et al. (2020b) identified slightly positive $\Delta^{33} \mathrm{~S}$ at Vailulu'u, associated with a dilute HIMU contribution, and demonstrate that the magnitude of the $\Delta^{33} \mathrm{~S}$ signature is consistent with a post-Archean recycled component (Dottin et al. 2020b). Furthermore, the $\Delta^{36} \mathrm{~S}$ versus $\Delta^{33} \mathrm{~S}$ relationship among basalts analyzed in Labidi et al. (2015) and Dottin et al. (2020b) also hint at a post-Archean age for the recycled S. The depleted mantle (DM) has been characterized for multiple S-isotopes and consistently show a negative $\delta^{34} \mathrm{~S}$ composition $\left(\sim-1 \%\right.$ ) and $\Delta^{33} \mathrm{~S}=0.008 \pm 0.006 \%$ orelative to CDT (Labidi et al., 2013, 2014). The negative $\delta^{34} \mathrm{~S}$ is argued to be a relic of core-formation (Labidi et al. 2013, 2014). With multiple localities for the HIMU, EM I, EM II, and DM endmembers characterized for S-isotopes, we can evaluate whether similar S-isotope signatures are entrained into the Samoan mantle plume, and further, whether the compositions are associated with values observed at endmember type localities, such as the HIMU signature at Mangaia. Similarity in S-isotope compositions among Samoan basalts and other OIB would imply that particular recycled components are globally distributed. Alternatively, differences in S-isotope composition among mantle endmembers would provide insight into the level of heterogeneity of S among the various flavors of mantle.

Here, we present new bulk rock quadruple sulfur isotope analyses of sulfide in basalts $(N=16)$ from a number of different localities along the Samoan hotspot track, including the Malumalu seamount, Malutut seamount, Savai'i island, Tutuila island, and Upolu island (Figure 1). We also present data from a reanalysis of AVON3-71-22. In this study, we exhaustively compile existing S-isotope data for the Samoan lavas and employ the new and published data to explore whether there are distinct S-isotope compositions revealed by basalts from the various geochemical trends. Although sulfates are known to occur in Samoan melts (Labidi et al., 2015), we focus solely on the sulfide-hosted S in whole rock samples with the goal of tracking 


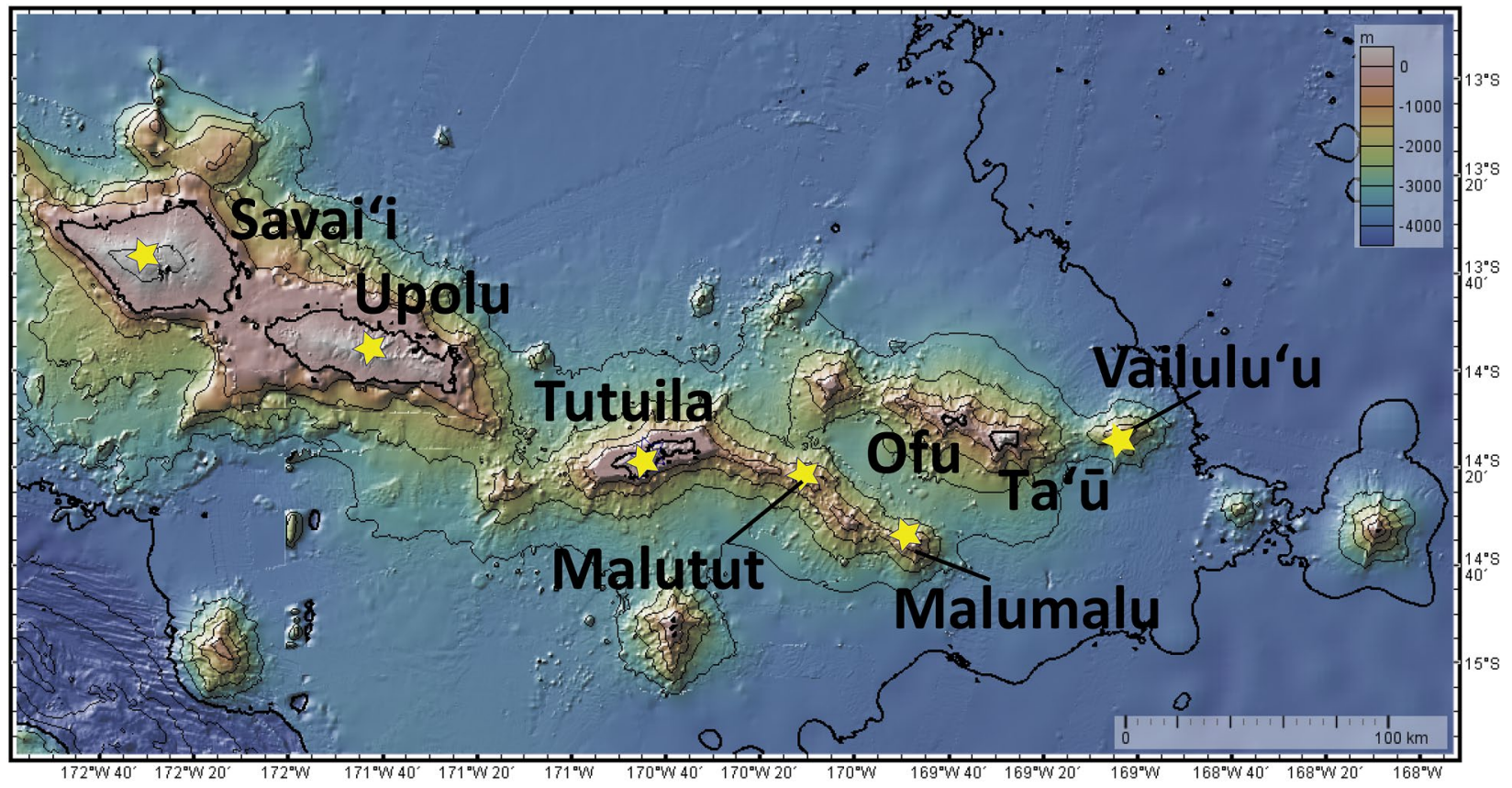

Figure 1. Map of Samoa. Stars denote islands or seamounts of samples characterized in this project. This map was generated using the GeoMap App.

potential $\Delta^{33} S$ and $\Delta^{36} \mathrm{~S}$ variations, which we hypothesize may be linked to distinct recycled sources. Furthermore, unlike pristine glass, the sulfate hosted in the whole rock material may have been modified by the composition of seawater. Ultimately, we take advantage of the S-isotope literature previously published on OIBs for reduced sulfur in basalts, and aim to draw potential connections among the various recycled protoliths delivered to mantle plumes.

\subsection{Geologic Background}

Work by Jackson et al. (2014) show that the islands of Samoa can be grouped into three geochemically defined volcanic trends that are analogous to the Loa and Kea volcanic trends in Hawaii (Abouchami et al., 2005; Weis et al., 2011): the Vai trend, the Malu trend, and the Upo trend (Figure 2); each of these three geographic trends exhibit geochemical fingerprints in shield-stage lavas that are resolvable from each other. Additionally, three of the Samoan islands (Savai'i, Upolu, and Tutuila) host a thin veneer of rejuvenated volcanism with a geochemical signature (major elements, trace elements and isotopic compositions) distinct from the shield stage lavas (Konter \& Jackson, 2012; Reinhard et al., 2019). The Vai trend is captured by the youngest chain of volcanic islands in Samoa and displays high ${ }^{206} \mathrm{~Pb} /{ }^{204} \mathrm{~Pb}$ that is attributed to influence from a shallow-level, dilute HIMU component (Workman et al., 2004), but the HIMU component may be embedded in the plume (Jackson et al., 2014). The Malu trend, captured by the second youngest group of islands, reflects influence from an EM II component, with high ${ }^{87} \mathrm{Sr} /{ }^{86} \mathrm{Sr}$ and higher ${ }^{208} \mathrm{~Pb} /{ }^{204} \mathrm{~Pb}$ for a given ${ }^{206} \mathrm{~Pb} /{ }^{204} \mathrm{~Pb}$. The Upo trend has low ${ }^{206} \mathrm{~Pb} /{ }^{204} \mathrm{~Pb}$ and high ${ }^{143} \mathrm{Nd} /{ }^{144} \mathrm{Nd}$, consistent with mixing between the Common (C) component and a depleted mantle component (Jackson et al., 2014; Workman et al., 2004). The rejuvenated basalts from Upolu, Savai'i and Tutuila sample a diluted EM I component that also has low ${ }^{206} \mathrm{~Pb} /{ }^{204} \mathrm{~Pb}$, with lower ${ }^{143} \mathrm{Nd} /{ }^{144} \mathrm{Nd}$ and higher ${ }^{208} \mathrm{~Pb} /{ }^{204} \mathrm{~Pb}$ at a given ${ }^{206} \mathrm{~Pb} /{ }^{204} \mathrm{~Pb}$ than the Samoan Upo components (Jackson et al., 2014). These four distinct compositional trends have been argued to reflect mixing between "C" and four geochemically distinct recycled components that are spatially separated in the Samoan mantle plume (Jackson et al., 2014). Their distinct lead isotope geochemistry provides an ideal framework for determining how sulfur from various sources is distributed in this plumbing system. 


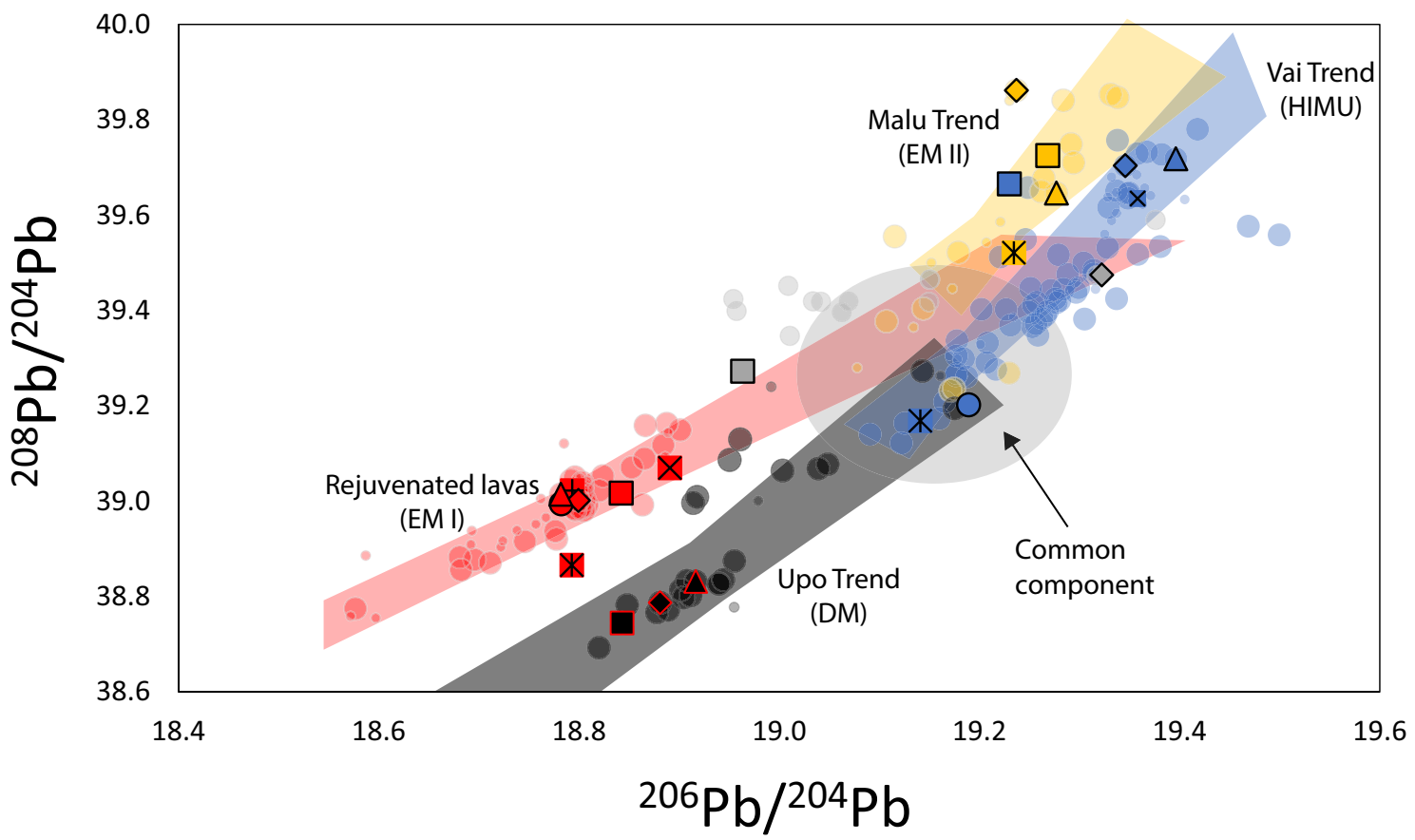

- Vai (HIMU)

O Ofu 05-18

* Ofu 04-15

AAVON3-73-1

$\triangle$ AVON3-70-9

$\triangle A V O N 3-71-22$

$\triangle$ AVON3-63-2

\begin{tabular}{|c|c|c|}
\hline Malu (EM II) & Upo (DM) & Rejuvenated (EM I) \\
\hline $\begin{array}{l}\triangle \text { AVON3-76-9 } \\
\square \text { AVON3-77-1 } \\
\diamond \text { AVON3-78-1 } \\
\text { * ALIA 108-04 }\end{array}$ & $\begin{array}{l}\text { 口 TUT99-01 } \\
\text { • U16 } \\
\text { \& U19 }\end{array}$ & $\begin{array}{l}\text { ×UPO-7a } \\
\text { OS } 11 \\
\text { ○ } 12 \\
\text { MS } 15 \\
\text { « S 26S } \\
\square \text { S 32M } \\
\triangle \text { ALIA 116-04 }\end{array}$ \\
\hline
\end{tabular}

Submarine Western Samoa

$\diamond$ ALIA 114-03

$\square$ ALIA 128-21

Figure 2. ${ }^{208} \mathrm{~Pb} /{ }^{204} \mathrm{~Pb}$ versus ${ }^{206} \mathrm{~Pb} /{ }^{204} \mathrm{~Pb}$ plot of Samoan basalts highlighting the geochemical trends (Vai, Malu, DM, and Rejuvenated) and the Common component after Jackson et al. (2014). We also highlight the samples analyzed (symbols with full color) for this study and Dottin et al. (2020b) to demonstrate the variety of compositions analyzed. Large symbols represent spiked Pb-isotope measurements via TIMS (Thermal Ionization Mass Spectrometry) and MC-ICPMS (Multi Collector-Inductively Coupled Mass Spectrometry). Small symbols represent un-spiked Pb-isotope TIMS data. The shaded regions are a representation of the $99 \%$ confidence interval around the best fit line plotted through each group of data (Jackson et al. 2014). Note that we do not plot data from MORB and Hawaii like that shown in Jackson et al. (2014)-this results in the grey shaded region extending further past what is plotted here.

\section{Materials and Methods}

Samples chosen for this study were collected on land and through dredging (AVON2/3 cruises) and were characterized for $\mathrm{Sr}-\mathrm{Nd}-\mathrm{Pb}-\mathrm{He}-\mathrm{Os}$ isotopes, trace elements, and major elements (Jackson et al., 2007a, 2007b, 2010; Workman et al., 2004). With the exception of samples from Upolu and Ta'u which show evidence for chemical weathering (Workman et al., 2004), all samples are interpreted to be pristine unaltered basalts (see supplementary information). In preparation for acid digestion, $\sim 3-6 \mathrm{~g}$ of whole rock chips from submarine pillow basalt interiors and subaerially erupted basalts were crushed in a steel mortar and pestle and sieved to $<56$ microns. Aliquots of $\sim 0.5-3 \mathrm{~g}$ of homogenized powder were then placed into Teflon reactors with stir bars. The Teflon reactors were subsequently connected to a water trap with plastic tubing and the water trap was connected to an $\mathrm{AgNO}_{3}$ trap where released sulfide would eventually precipitate as $\mathrm{Ag}_{2} \mathrm{~S}$. Prior to acidification, a digestion set-up similar to that presented in Labidi et al. (2012) was purged with $\mathrm{N} 2$ for approximately $10-15 \mathrm{~min}$. After purging $20 \mathrm{ml}$ of $\mathrm{CrCl}_{2}, 10 \mathrm{ml}$ of $\mathrm{HCl}$, and $10 \mathrm{ml}$ of $\mathrm{HF}$ were injected into the Teflon reactors through a two-way valve with flowing $\mathrm{N}_{2}$ through a separate port. After acidification, the sample and reagents were heated to $\sim 80^{\circ} \mathrm{C}$ and stirred with a magnetic stir bar for better powder digestion and to avoid the formation of fluorides which can inhibit the release of sulfide. During this reaction, sulfides in the powder are released as $\mathrm{H}_{2} \mathrm{~S}$, that is then carried through the water trap to the acid trap, and then bubbled through the $\mathrm{AgNO}_{3}$ trap to precipitate sulfide as $\mathrm{Ag}_{2} \mathrm{~S}$. The reaction ran for $\sim 3 \mathrm{~h}$. Once the reaction was complete, samples were stored in the dark for a minimum of three days and 
subsequently rinsed and centrifuged in $1.5 \mathrm{ml}$ Eppendorf tubes six times with Milli-Q water. After rinsing, samples were dried for $\sim 2 \mathrm{~h}$ at $70^{\circ} \mathrm{C}$, weighed (to calculate $\mathrm{S}$ concentration), and wrapped in foil in preparation for fluorination. $\mathrm{S}$ contents of the basalts are estimated from the weight of collected $\mathrm{S}$ during extraction. We take our one standard deviation uncertainty on $\mathrm{S}$ concentration from extractions to be $18 \mathrm{ppm}$, as determined from repeat extractions $(n=4)$ of AVON3-71-22.

\subsection{Fluorination}

Samples of silver sulfide $(\sim 0.2-\sim 3 \mathrm{mg})$ in foil packets were placed into nickel reaction tubes and reacted with three to five times excess fluorine overnight to produce $\mathrm{SF}_{6}$. Produced $\mathrm{SF}_{6}$ was first frozen into a liquid nitrogen trap and excess fluorine was passivated through a heated $\mathrm{KBr}$ salt. The remaining frozen gas was thawed with an ethanol slush $\left(\sim-108^{\circ} \mathrm{C}\right.$ to $\left.-110^{\circ} \mathrm{C}\right)$ to separate $\mathrm{SF}_{6}$ from $\mathrm{HF}$ (also produced during the overnight fluorination). The separated $\mathrm{SF}_{6}$ was frozen into a separate coil and injected into a gas chromatograph with $\mathrm{He}$ flow. Using peak monitoring software, we were able to trap the purified $\mathrm{SF}_{6}$ with liquid nitrogen in metal coils. After trapping, we manometrically calculated yields of fluorination, which varied from $78 \%$ to $108 \%$ for this study. Note that excess yields up to $108 \%$ in this study can represent either weighing errors or the known slight calibration drift of the pressure gauge that can result in $>100 \%$ yields during complete fluorination of standards.

\subsection{Mass Spectrometry}

The purified $\mathrm{SF}_{6}$ was next analyzed using a ThermoFinnigan MAT 253 dual-inlet gas source mass spectrometer. All samples were analyzed as nine sets of eight 26-s cycles of measurements (of both the reference gas and the sample gas) and bracketed with analyses of a single reservoir of IAEA-S1 standard materials. All samples were first normalized to IAEA-S1 analyses conducted during the analytical session and then subsequently renormalized to IAEA-S1 relative to CDT that places IAEA-S1 at $-0.401 \%$, $0.116 \%$, $0.796 \%$ o for $\delta^{34} \mathrm{~S}, \Delta^{33} \mathrm{~S}$, and $\Delta^{36} \mathrm{~S}$ respectively (Antonelli et al., 2014). Generally, our estimated uncertainty on measurements (all $2 \sigma$ ) is $0.3 \%$ o, $0.008 \%$, and $0.3 \%$ o for $\delta^{34} \mathrm{~S}, \Delta^{33} \mathrm{~S}$, and $\Delta^{36} \mathrm{~S}$ respectively and is estimated from long-term uncertainty on measurements of IAEA-S1. However, for smaller samples (U16, U19, S15), the uncertainty on $\Delta^{33} \mathrm{~S}$ is estimated at $0.016 \%$ as an upper limit. The difference in uncertainty for smaller samples reflects larger analytical uncertainty in measurements on ${ }^{33} \mathrm{~S}$. We note that the uncertainty on $\Delta^{33} \mathrm{~S}$ is primarily analytical (Dottin et al., 2020b) whereas the estimated uncertainty reported on $\delta^{34} \mathrm{~S}$ and $\Delta^{36} \mathrm{~S}$ includes uncertainty associated with sample processing through wet chemistry and fluorination. Note that in Dottin et al. (2020b) AVON3-63-2 and AVON3-70-9 have $\Delta^{33}$ S uncertainty of $0.016 \%$ as a result of shorter analytical sessions.

\section{Results}

Whole rock S-isotope data and S concentrations from basalts that sample the various Samoan Islands from subaerial and submarine eruptions are presented in Figure 3 and Table 1. Unlike Hawaii, where shield stage lavas tend to be tholeiitic and rejuvenated stage lavas are alkalic, Samoan shield stage and rejuvenated stage lavas are both overwhelmingly alkalic in composition, and the samples targeted in this study are alkali basalts (see Jackson et al., 2010, 2007a; Workman et al., 2006, 2004 for details). While a prior study of Samoan lavas targeted submarine pillow glass (Labidi et al., 2015), here we followed the method of Dottin et al. (2020b) and analyzed whole rock basalts for sulfide material. Reduced sulfur concentrations in our samples range from 10 to 1,000 ppm. Analyzed subaerial whole rock lavas typically have lower S concentrations relative to the $S$ concentrations from whole rock submarine lavas and glasses, indicative of sulfur loss via degassing. One exception is the western Samoa submarine lava sample ALIA-114-03, where the basalt was collected by dredging at $\sim 2500 \mathrm{~m}$ depth but has an S concentration of $32 \mathrm{ppm}$, which may represent a sample erupted shallowly but then was simply transported downslope following eruption (Figure S1).

The new data are from Valulu'u, Malumalu, Malutut, Savai‘i, Upolu, and Tutuila. Submarine samples from Malumalu seamount $\left(N=2\right.$ ) have S-isotope compositions (AVON3-78-1: $\delta^{34} \mathrm{~S}=1.73 \%$ o \pm .30, $\Delta^{33} \mathrm{~S}=0.000 \%$ $\pm 0.008, \Delta^{36} \mathrm{~S}=-0.05 \%$ \pm 0.30 ; AVON3-76-9: $\delta^{34} \mathrm{~S}=1.79 \%$ $\pm 0.30, \Delta^{33} \mathrm{~S}=-0.003 \% \circ \pm 0.008$, $\Delta^{36} \mathrm{~S}=0.01 \%$ o \pm 0.30 [all $\left.2 \sigma\right]$ ) that are within the range (including uncertainty) of previously reported data on 

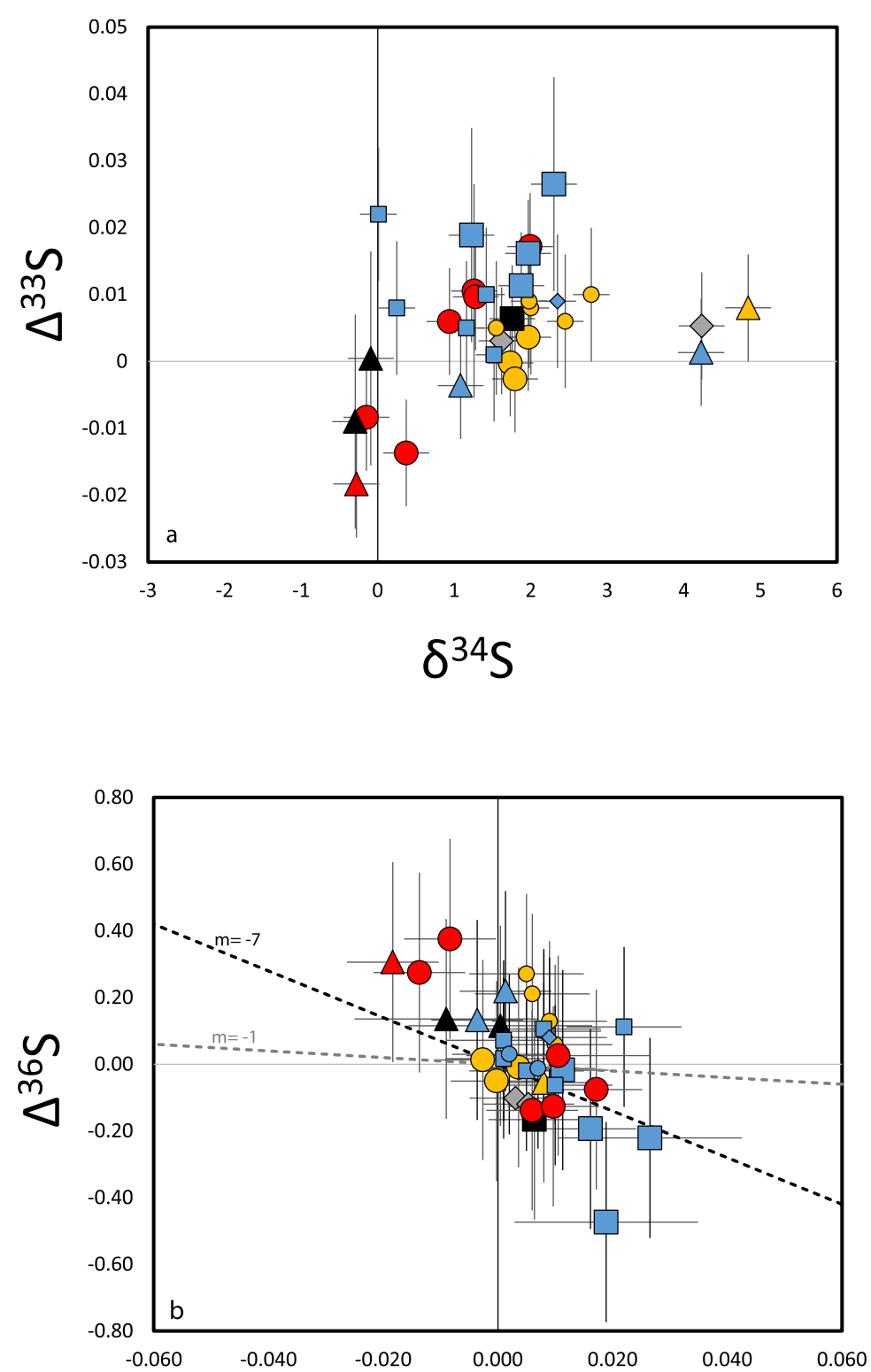

$\Delta^{33} S$

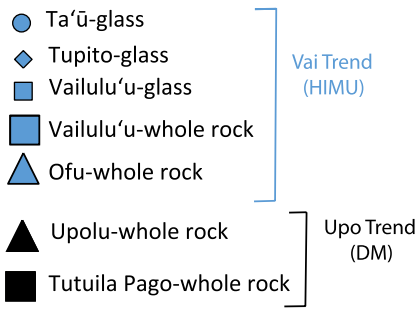

$\left.\begin{array}{l}\left.\begin{array}{l}\triangle \text { Upolu rejuvenated-whole rock } \\ \text { Savai'i rejuvenated-whole rock }\end{array}\right] \begin{array}{c}\text { Rejuvenated Lavas } \\ \text { (EM I) }\end{array} \\ \begin{array}{l}\text { Malumalu-glass } \\ \text { Malu Trend } \\ \text { (EM II) }\end{array} \\ \triangle \text { Malumalu-whole rock } \\ \diamond \text { Savai'i submatut-whole rock }\end{array}\right] \begin{gathered} \\ \triangle\end{gathered}$


Malumalu $\left(\delta^{34} \mathrm{~S}=1.45-2.69 \%\right.$ \pm 0.24 relative to CDT, $\Delta^{33} \mathrm{~S}=0.004 \%$ to $0.01 \% \circ \pm 0.010$, and $\Delta^{36} \mathrm{~S}=-0.01 \%$ o to $0.271 \%$ o $\pm 0.18, n=6$ ) which have been reported for sulfur from fresh glass (Labidi et al., 2015) and whole rock powders (Dottin et al. 2020b). Note, estimated S concentrations for the submarine Malumalu samples (AVON3-78-1 = 361 ppm S; AVON3-76-9 = 449 ppm S) are slightly lower, or at the lower end of the range, of S concentrations previously reported on Malumalu samples (393-1,693 ppm S) (Dottin et al., 2020b; Labidi et al., 2015). The data for the one submarine sample from the Malutut seamount, which is geochemically similar to Malumalu in sampling an EM II component, has a S concentration of $81 \mathrm{ppm}$ (ALIA 108-04) and an S-isotope composition of $\delta^{34} \mathrm{~S}=4.89 \% \circ \pm 0.30, \Delta^{33} \mathrm{~S}=0.008 \% \circ \pm 0.008$, and $\Delta^{36} \mathrm{~S}=-0.06 \% \circ \pm 0.30$. The reanalysis of AVON3-71-22 shows a similar S-isotope composition that is within uncertainty of the originally published composition $\left(\delta^{34} \mathrm{~S}=2.09 \% \circ \pm 0.30, \Delta^{33} \mathrm{~S}=0.009 \% \circ \pm 0.008, \Delta^{36} \mathrm{~S}=0.08 \% \circ \pm 0.30\right.$, Dottin et al. [2020b]) but, exhibits a higher S concentration (1,038 ppm S [this study] vs. 603 ppm S [Dottin et al., 2020b]). Western Samoan submarine lavas from Savai'i have S concentrations of 32 and $219 \mathrm{ppm}$ and S-isotope compositions of $\delta^{34} \mathrm{~S}=1.62 \pm 0.30, \Delta^{33} \mathrm{~S}=0.003 \pm 0.008, \Delta^{36} \mathrm{~S}=-0.10 \pm 0.30$ and $\delta^{34} \mathrm{~S}=4.23 \pm 0.30$, $\Delta^{33} \mathrm{~S}=0.005 \pm 0.008, \Delta^{36} \mathrm{~S}=-0.12 \pm 0.30$ for ALIA 114-03 and ALIA 128-21, respectively. Tutuila and Upolu subaerial lavas from the Upo trend (DM) have S concentrations that range from 9 to $69 \mathrm{ppm}$, with S-isotope ratios that range from -0.29 to $1.76,-0.009$ to 0.006 , and -0.17 to 0.14 in $\delta^{34} \mathrm{~S}, \Delta^{33} \mathrm{~S}$, and $\Delta^{36} \mathrm{~S}$ respectively. Rejuvenated stage subaerial basalts from Savai'i and Upolu have S concentrations that range from 15 to $83 \mathrm{ppm}$ and show a slightly different $\mathrm{S}$-isotope composition with values ranging from $-0.28 \%$ o to $1.28 \%$ o in $\delta^{34} \mathrm{~S},-0.018$ to 0.011 in $\Delta^{33} \mathrm{~S}$, and -0.14 to 0.38 in $\Delta^{36} \mathrm{~S}$. The rejuvenated submarine basalt from Savai' $\mathrm{i}$, ALIA116-04, has an S-isotope composition of $\delta^{34} \mathrm{~S}=1.99 \pm 0.30, \Delta^{33} \mathrm{~S}=0.017 \pm 0.008, \Delta^{36} \mathrm{~S}=-0.08 \pm 0.30$. The samples from rejuvenated volcanism show the largest range in $\Delta^{33} \mathrm{~S}$ for a single geochemical grouping of Samoan basalts reported thus far, with $\Delta^{33} \mathrm{~S}$ that ranges from $-0.018 \%$ o to $0.017 \%$. The highest and lowest $\Delta^{33} \mathrm{~S}$ values in Samoa range from $+0.027 \pm 0.016$ (Dottin et al., 2020b) to $-0.018 \pm 0.008$ (this study), and the highest and lowest $\Delta^{36} \mathrm{~S}$ values are $0.31 \pm 0.30$ (this study) to $-0.47 \pm 0.18$ (Labidi et al., 2015), demonstrating resolvable $\Delta^{33} \mathrm{~S}$ and $\Delta^{36} \mathrm{~S}$ heterogeneity in the Samoan plume. After filtering subaerially erupted lavas, which are degassed (and therefore have $\delta^{34} \mathrm{~S}$ that no longer represents the mantle source composition), the submarine pillow basalts and pillow basalt glasses exhibit a range in $\delta^{34} \mathrm{~S}$ that extends from $0.11 \pm 0.24$ (Labidi et al., 2015) to $4.84 \pm 0.30$ (this study).

\section{Discussion}

\subsection{Variable S Contents in Submarine Basalts}

We analyzed sulfide extracted from submarine and subaerial whole rock powders and determined S contents that range from $\sim 10$ to $1,000 \mathrm{ppm} \mathrm{S}$. In some cases, the $\mathrm{S}$ concentrations reported in submarine whole rocks are lower than the lowest $S$ concentration observed in Samoan glasses ( $\sim 600$ ppm, Labidi et al., 2015). The lower concentrations may simply be an effect of dilution in whole rocks versus glasses and, without extensive knowledge as to where sulfides reside in the rock, an effect of dilution cannot be ruled out. Furthermore, the variable S concentrations and S-isotope compositions raise the question as to whether there are other processes at play that contribute to the extremely low S contents. For the samples analyzed, we must consider degassing as a means of altering $\mathrm{S}$ concentrations and $\mathrm{S}$-isotope compositions.

Although sulfide segregation is known to occur in Samoan basalts, it is difficult to discern its potential effect on $\mathrm{S}$ concentrations as there are no clear links between $\mathrm{S}$ contents, eruption depth, $\mathrm{MgO}$ and $\mathrm{Cu}$ contents (Workman et al., 2006, 2004) (Figure S2). Sulfide segregation could produce $\delta^{34}$ S variations, especially in a system with coexisting sulfide and sulfate assuming the $\mathrm{S}$ pools remain in isotopic equilibrium $(\sim 3 \%$, Miyoshi et al., 1984; also see Fiege et al., 2014). Sulfate at Samoa was shown to host more positive $\delta^{34} \mathrm{~S}$ than the coexisting sulfide (Labidi et al., 2015). If sulfide is lost to a process such as sulfide segregation, the presence an $\mathrm{S}$ speciation buffer (such as dissolved Fe) would cause the sulfate/total sulfur ratio to remain constant

Figure 3. Sulfur isotope data for reduced sulfur from Samoan basalts. (a) $\Delta^{33} S$ versus $\delta^{34} S$ of Samoan basalts. (b) $\Delta^{36} S$ versus $\Delta^{33} S$ of Samoan basalts. Data presented are from this study (whole rock powders), Labidi et al. (2015) (glasses) and Dottin et al. (2020b) (whole rock powders). Error bars represent 2 sigma uncertainty. Large symbols indicate sulfide data from whole rocks (Dottin et al., 2020b, this study). Small symbols indicate sulfide data from glasses (Labidi et al., 2015). Note that we have not removed subaerial lavas from this plot which are highly degassed and likely have modified $\delta^{34} \mathrm{~S}$ compositions. Muli is renamed as Tupito. The slopes plotted represent the slope for the Archean $(m=-1)$ and post-Archean $(m=-7)$ sedimentary rock data compilations (e.g. Johnston, 2011). 
Table 1

Compilation of S-Isotope Compositions for Samoan Basalts

\begin{tabular}{|c|c|c|c|c|c|c|c|c|c|}
\hline Sample & Dredge depth (m) & Location & $\mathrm{S}(\mathrm{ppm})$ & $\delta^{34} \mathrm{~S}$ & $2 \sigma$ & $\Delta^{33} S$ & $2 \sigma$ & $\Delta^{36} \mathrm{~S}$ & $2 \sigma$ \\
\hline \multicolumn{10}{|l|}{ Rejuvenated Lavas } \\
\hline UPO-7A & subaerial & Upolu & 45 & -0.28 & 0.30 & -0.018 & 0.008 & 0.31 & 0.30 \\
\hline S 11 & subaerial & Savai'i & 28 & 0.94 & 0.30 & 0.006 & 0.008 & -0.14 & 0.30 \\
\hline S 15 & subaerial & Savai'i & 15 & 1.26 & 0.30 & 0.011 & 0.008 & 0.03 & 0.30 \\
\hline S 12 & subaerial & Savai'i & 31 & 0.37 & 0.30 & -0.014 & 0.008 & 0.27 & 0.30 \\
\hline S $32 \mathrm{M}$ & subaerial & Savai'i & 83 & 1.28 & 0.30 & 0.010 & 0.008 & -0.13 & 0.30 \\
\hline S 26S & subaerial & Savai'i & 52 & -0.15 & 0.30 & -0.008 & 0.008 & 0.38 & 0.30 \\
\hline ALIA 116-04 & 2,510 & Savai'i & 655 & 1.99 & 0.30 & 0.017 & 0.008 & -0.08 & 0.30 \\
\hline \multicolumn{10}{|c|}{ Upo Volcanic Lineament } \\
\hline U 16 & subaerial & Upolu & 11 & -0.09 & 0.30 & 0.000 & 0.008 & 0.12 & 0.30 \\
\hline U19 & subaerial & Upolu & 9 & -0.29 & 0.30 & -0.009 & 0.008 & 0.14 & 0.30 \\
\hline TUT 99-01 & subaerial & Tutuila & 69 & 1.76 & 0.30 & 0.006 & 0.008 & -0.17 & 0.30 \\
\hline \multicolumn{10}{|c|}{ Malu Volcanic Lineament } \\
\hline AVON3-78-1 & 2,264 & Malumalu & 361 & 1.73 & 0.30 & 0.000 & 0.008 & -0.05 & 0.30 \\
\hline AVON3-76-9 & 2,393 & Malumalu & 449 & 1.79 & 0.30 & -0.003 & 0.008 & 0.01 & 0.30 \\
\hline${ }^{\mathrm{a}} \mathrm{AVON} 3-77-1$ & 3,605 & Malumalu & 393 & 1.97 & 0.30 & 0.004 & 0.008 & -0.01 & 0.30 \\
\hline bAVON3-76-11 & 2,393 & Malumalu & 1,693 & 2.79 & 0.24 & 0.010 & 0.010 & 0.059 & 0.18 \\
\hline b AVON3-76-13 & 2,393 & Malumalu & 1,289 & 1.55 & 0.24 & 0.005 & 0.010 & 0.271 & 0.18 \\
\hline${ }^{\mathrm{b}} \mathrm{AVON} 3-76-3$ & 2,393 & Malumalu & 1,348 & 2.00 & 0.24 & 0.008 & 0.010 & 0.099 & 0.18 \\
\hline${ }^{\mathrm{b}}$ AVON3-76-6 & 2,393 & Malumalu & 1,514 & 2.45 & 0.24 & 0.006 & 0.010 & 0.211 & 0.18 \\
\hline${ }^{\mathrm{b}} \mathrm{AVON} 3-76-8$ & 2,393 & Malumalu & 1,435 & 1.98 & 0.24 & 0.009 & 0.010 & 0.129 & 0.18 \\
\hline ALIA108-04 & 3,200 & Malutut & 81 & 4.84 & 0.30 & 0.008 & 0.008 & -0.06 & 0.30 \\
\hline \multicolumn{10}{|c|}{ Vai Volcanic Lineament } \\
\hline${ }^{\mathrm{a} O F U-04-15}$ & subaerial & Ofu & 64 & 4.23 & 0.30 & 0.001 & 0.008 & 0.22 & 0.30 \\
\hline${ }^{\mathrm{a} O F U-04-06}$ & subaerial & Ofu & 29 & 1.08 & 0.30 & -0.004 & 0.008 & 0.13 & 0.30 \\
\hline AVON3-71-22 (Avg) & 4,170 & Vailulu'u & 1,038 & 1.97 & 0.30 & 0.016 & 0.008 & -0.19 & 0.30 \\
\hline${ }^{\mathrm{a} A V O N 3-63-2}$ & 920 & Vailulu'u & 809 & 1.23 & 0.30 & 0.019 & 0.016 & -0.47 & 0.30 \\
\hline a AVON3-70-9 & 1,130 & Vailulu'u & 201 & 2.30 & 0.30 & 0.027 & 0.016 & -0.22 & 0.30 \\
\hline${ }^{\mathrm{a}} \mathrm{AVON} 3-73-1$ & 960 & Vailulu'u & 214 & 1.88 & 0.30 & 0.01 & 0.008 & -0.02 & 0.30 \\
\hline bAVON3-71-13 & 4,170 & Vailulu'u & 1,755 & 1.52 & 0.24 & 0.010 & 0.010 & -0.063 & 0.18 \\
\hline bAVON3-71-11 & 4,170 & Vailulu'u & 1,794 & 1.62 & 0.24 & 0.001 & 0.010 & 0.017 & 0.18 \\
\hline${ }^{\mathrm{b}}$ AVON3-71-2 & 4,170 & Vailulu'u & 1,768 & 1.26 & 0.24 & 0.005 & 0.010 & -0.020 & 0.18 \\
\hline${ }^{\mathrm{b}}$ AVON3-68-3 & 780 & Vailulu'u & 800 & 0.35 & 0.24 & 0.008 & 0.010 & 0.106 & 0.18 \\
\hline${ }^{\mathrm{b}}$ AVON3-73-12 & 960 & Vailulu'u & 600 & 0.11 & 0.24 & 0.022 & 0.010 & 0.112 & 0.18 \\
\hline${ }^{\mathrm{b}} \mathrm{AVON} 3-752$ & 2,675 & Ta'ū & 651 & 1.18 & 0.24 & 0.002 & 0.010 & 0.030 & 0.18 \\
\hline${ }^{\mathrm{b}}$ AVON3-75-10 & 2,675 & $\mathrm{Ta}^{\natural} \overline{\mathrm{u}}$ & 819 & 0.62 & 0.24 & 0.001 & 0.010 & 0.072 & 0.18 \\
\hline${ }^{\mathrm{b}}$ AVON3-75-15 & 2,675 & $\mathrm{Ta}^{\star} \overline{\mathrm{u}}$ & 945 & 1.45 & 0.24 & 0.007 & 0.010 & -0.013 & 0.18 \\
\hline${ }^{\mathrm{b}} \mathrm{AVON} 3-74-2$ & 2,544 & $\mathrm{Ta}^{\star} \overline{\mathrm{u}}$ & 1,575 & 0.77 & 0.24 & 0.003 & 0.010 & & \\
\hline${ }^{\mathrm{b}} \mathrm{AVON} 3-79-4$ & 3,484 & Tupito & 880 & 2.45 & 0.24 & 0.009 & 0.010 & 0.080 & 0.18 \\
\hline \multicolumn{10}{|c|}{ Submarine western Samoan lavas } \\
\hline ALIA 114-03 & 2,510 & Savai'i submarine & 32 & 1.62 & 0.30 & 0.003 & 0.008 & -0.10 & 0.30 \\
\hline ALIA 128-21 & 2,560 & Savai'i submarine & 219 & 4.23 & 0.30 & 0.005 & 0.008 & -0.12 & 0.30 \\
\hline
\end{tabular}

Note: Avg $=$ average of $n=2$ analyses.

${ }^{\mathrm{a}}$ Data from Dottin et al., 2020b. ${ }^{\mathrm{b}}$ Data from Labidi et al., 2015. 
through sulfate reduction and by mass balance would cause the $\delta^{34} \mathrm{~S}$ composition of the sulfide in the melt to constantly increase. Labidi et al. (2015) argue however, that sulfides remain unfractionated for $\delta^{34} \mathrm{~S}$, at odds with requirement of a S speciation buffer. Thus, although our samples affected by sulfide segregation may have very low $\mathrm{S}$ contents, the $\delta^{34} \mathrm{~S}$ could conceivably still represent that of the melt composition and not a process associated with sulfide segregation.

\subsubsection{The Effect of Degassing on $\delta^{34} \mathrm{~S}$ and $\mathrm{S}$ Concentrations}

Many of the basalts analyzed here are from subaerial eruptions and likely have experienced modification of the $\delta^{34} \mathrm{~S}$ composition from degassing processes. For those samples, we interpret both the $\delta^{34} \mathrm{~S}$ data and the $\mathrm{S}$ concentrations to reflect sulfur loss from degassing and note that it is problematic to attribute the observed $\delta^{34} \mathrm{~S}$ values directly to the original values of the source. We additionally note that some of the submarine basalts host low $\mathrm{S}$ concentrations (e.g. sample ALIA114-03, dredged at 2,510 m water depth, has $32 \mathrm{ppm} \mathrm{S}$ and ALIA 108-04, dredged at $3200 \mathrm{~m}$ with $81 \mathrm{ppm} \mathrm{S}$; see Table 1) that may reflect degassing or weathering. We do not observe any correlation between indicators of basalt alteration $(\mathrm{Ba} / \mathrm{Rb})$, sulfur isotope compositions, and sulfur concentrations, suggesting that weathering is not a key driver for sulfur isotope and sulfur concentration variations (Figure S3). Furthermore, we note that the depth of collection may not always correspond to the depth of eruption. For example, the low S concentrations may be linked to degassing, as a lava dredged at depth may have erupted at shallow levels and was then transported downslope. Alternatively, a volcano can erupt lavas at shallow levels during an early shield stage-where ALIA-114-03 was erupted at $\sim 4 \mathrm{Ma}$ (Koppers et al., 2008) during the early shield stage on Savai'i-and then experience thermal subsidence, thereby explaining a shallow eruption origin for a deeply sampled basalt. The depth of eruption therefore remains elusive for such samples.

Degassing is well documented as an agent responsible for modifying both $\delta^{34} \mathrm{~S}$ and S concentrations (e.g., Mandeville et al., 2009; Moore \& Fabbi, 1971), including for basalts from Samoa (Dottin et al., 2020b) and the Canary Islands (Beaudry et al., 2018). At the Quartz-Fayalite-Magnetite reaction buffer the speciation of $\mathrm{S}$ in the melt is primarily $\mathrm{S}^{(2-)}, \mathrm{SO}_{2}$ dominates the gas phase, and there is significant loss of $\mathrm{SO}_{2}$ at pressures less than 100 bars (Burgisser et al., 2015; Gaillard \& Scaillet, 2009). Under equilibrium at $1,200^{\circ} \mathrm{C}, \mathrm{SO}_{2}$ is argued to be ${ }^{32}$ S-enriched by $\sim 0.8$ (Marini et al., 2011) or $\sim 2 \%$ o relative to $\mathrm{S}^{2-}$ (Mandeville et al., 2009), resulting in a decrease in $\delta^{34} \mathrm{~S}$ of residual sulfide as $\mathrm{SO}_{2}$ is degassed. Alternatively, if gas is rapidly lost, kinetic degassing results in the loss of ${ }^{32} \mathrm{~S}$-enriched $\mathrm{SO}_{2}$, and residual sulfide may be enriched in ${ }^{34} \mathrm{~S}$ (e.g., de Moor et al., 2013). At more oxidizing conditions (e.g., QFM +1-5) and higher pressures (e.g. 3,000 bars) it is expected that loss of $\mathrm{SO}_{2}$ would result in an increase in $\delta^{34} \mathrm{~S}$ within the residual melt (e.g. Beaudry et al., 2018) at equilibrium. An additional complication is that the $\mathrm{fO}_{2}$ of the melt can change drastically upon decompression which can change $S$ speciation in both the melt and gas phase and ultimately change the associated fractionation with $\mathrm{S}$ degassing (Beaudry et al., 2018). We observe $\delta^{34} \mathrm{~S}$ values that range from $\sim 0$ to $\sim 5 \%$ o among the submarine and subaerial basalts. Subaerial basalts with very low $\mathrm{S}$ contents $(\mathrm{S}$ ppm $<65)$ have variable $\delta^{34} \mathrm{~S}$. With the exception of Ofu $04-15$ that shows very positive $\delta^{34} \mathrm{~S}$ of $+4.23 \%$ o with 64 ppm S (Dottin et al., 2020b), all subaerial samples with $\mathrm{S} \mathrm{ppm}<65$ show a dramatic decrease in $\delta^{34}$ S toward increasingly lower values, below $\sim+2 \%$ (Figure $\mathrm{S} 1 \mathrm{~b}$ ).

In consideration of the nature of samples (whole rocks, in some cases erupted subaerially) we are unable to interpret all $\delta^{34} \mathrm{~S}$ data collected as a representation of the source composition. In particular, for the subaerial basalts, the composition likely represents a mixture of source compositions and degassing. Thus, we only refer to non-degassed samples (excluding lavas erupting at depths $<\sim 1000 \mathrm{~m}$ as they typically show no difference in $\delta^{34} \mathrm{~S}$ relative to glasses reported in Labidi et al., 2015) in any discussion of the $\delta^{34} \mathrm{~S}$ data. Nonetheless, variations in $\Delta^{33} \mathrm{~S}$ are much less susceptible to measurable variations from degassing (although there may be a potential for this to occur during kinetic S loss, e.g., [Eiler et al., 2013]) and thus provides an opportunity to explore whether the proposed distinct recycled components at Samoa can be identified with unique $\Delta^{33} \mathrm{~S}$ and $\Delta^{36} \mathrm{~S}$. For example, in a plot of $\Delta^{33} \mathrm{~S}$ for each sample (Figure 4), the data appear to present possible differences in composition when grouped according to criteria described in Jackson et al. (2014), making it plausible that relationships may exist between sulfur and the geochemical mixing trends identified in that study. 


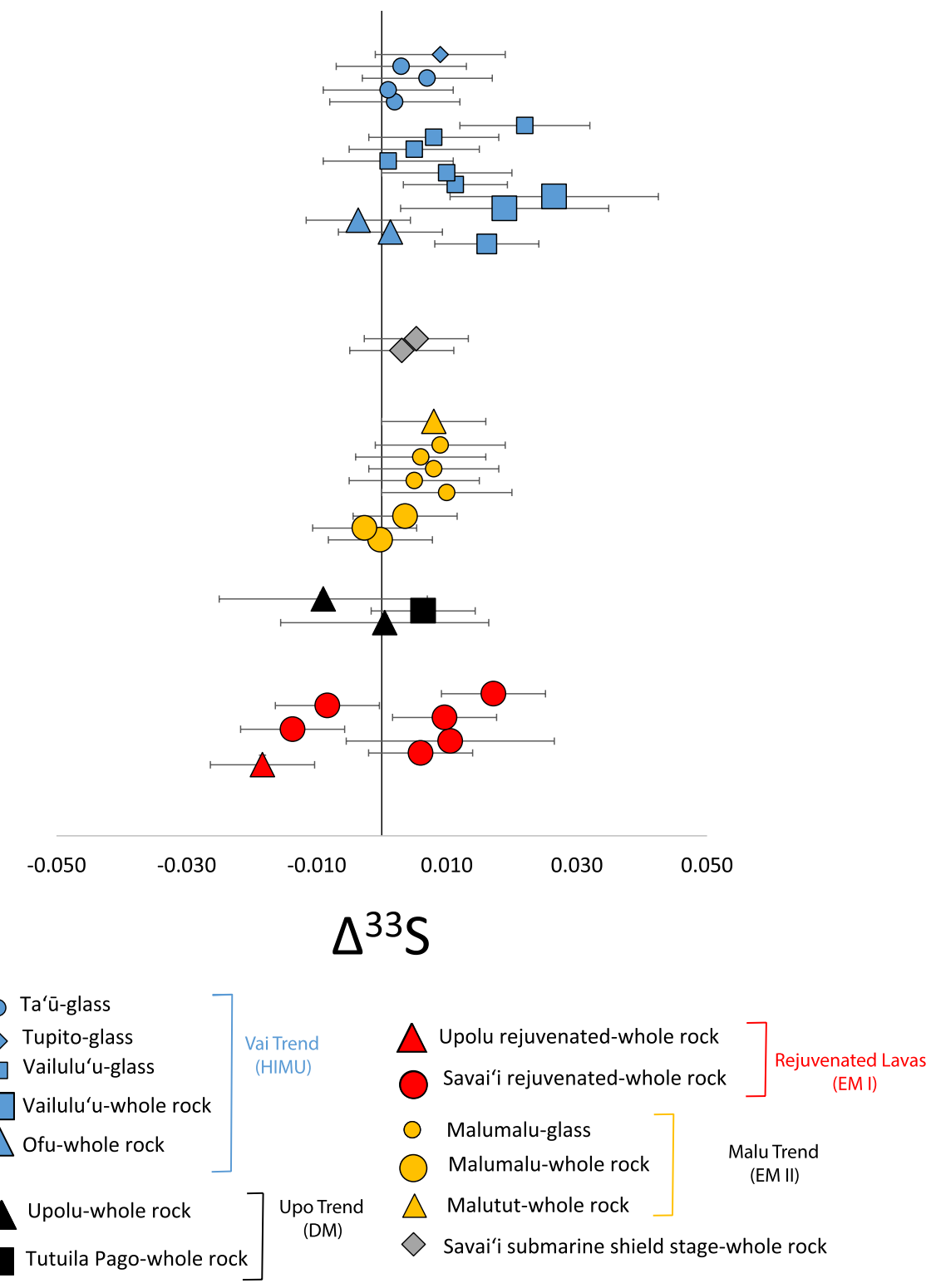

Figure 4. $\Delta^{33} \mathrm{~S}$ of each sample and their associated geochemical trend. Data from the Vai Trend and Malu trend include data collected in Labidi et al. (2015) and Dottin et al. (2020b). Large symbols represent whole rock analyses. Small symbols represent glasses. S-isotope data are from reduced sulfur in whole rocks and glasses. Muli is renamed as Tupito.

\subsection{Evidence for Recycled Crust in S-Isotope Compositions}

Crustal recycling is known to modify the S-isotope composition of basalts at Samoa. The Pacific upper mantle $\mathrm{S}$-isotope composition is estimated at $\delta^{34} \mathrm{~S}=-0.89 \pm 0.24$ and $\Delta^{33} \mathrm{~S}=0.008 \pm 0.012$ (all $2 \sigma$, Labidi et al., 2014) and the primordial sulfur isotope composition of the mantle is estimated at $\Delta^{33} \mathrm{~S}=0.000 \pm 0.008$ ( $2 \sigma$, Dottin et al., 2020b). With compositional estimates close to the origin for both $\delta^{34} \mathrm{~S}$ and $\Delta^{33} \mathrm{~S}$ in the mantle, any measured values that strongly deviate from these estimates are likely due to crustal recycling (with the exception of samples modified syn or post-eruption). At Samoa, the role of recycling has been documented to result in positive $\delta^{34} \mathrm{~S}$ in lavas (Labidi et al., 2015). The $\delta^{34} \mathrm{~S}$ values are positively correlated with ${ }^{87} \mathrm{Sr} /{ }^{86} \mathrm{Sr}$ in Samoan lavas and have been argued to be linked to a sedimentary protolith with a $\delta^{34} \mathrm{~S}$ composition of $\sim+10 \%$ o (Labidi et al., 2015). $\Delta^{33} \mathrm{~S}$ values have been documented as generally near zero for 
Samoan basalts with the exception of 1 sample with slightly positive $\Delta^{33} \mathrm{~S}(0.027 \pm 0.016)$ that is associated with a HIMU influence (Dottin et al., 2020b).

In the following sections we continue to evaluate the role of crustal recycling through characterization of basalts associated with the volcanic trends at Samoa and offer new insights into the role of plume zonation in the distribution of recycled components among the islands. The ${ }^{208} \mathrm{~Pb} /{ }^{204} \mathrm{~Pb}$ versus ${ }^{206} \mathrm{~Pb} /{ }^{204} \mathrm{~Pb}$ compositions at Samoa reveal four trends that radiate from a common composition associated with high ${ }^{3} \mathrm{He} /{ }^{4} \mathrm{He}$, termed the Common component (Hanan \& Graham, 1996; Jackson et al., 2014). The four trends extend from an intersection associated with the Common component to four distinct endmembers that sample a DM component (Upo-trend lavas), a dilute HIMU component (Vai trend lavas), an EM II component (Malu trend lavas), and an EM I component (rejuvenated lavas) (Figure 2). We hereby explore the S-isotope signatures of these four components below.

\subsection{Geochemical Zones of the Samoan Hotspot}

\subsubsection{Upo Trend-the DM Component}

Shield stage basalts from the Upolu Island and Pago volcanic series from Tutuila represent samples from some of the oldest parts of the hotspot track and exhibit $\mathrm{Pb}$-isotope compositions that link them to DM-like components (Jackson et al., 2014). Our three samples from the Upo trend (DM) (U16, U19, and TUT 9901, all of which erupted subaerially) have $\Delta^{33} \mathrm{~S}$ and $\Delta^{36} \mathrm{~S}$ within uncertainty of that reported for the MORB mantle. The S-isotope composition of the upper mantle, based on the average S-isotope composition of 80 non-degassed MORB samples, is estimated at $\Delta^{33} \mathrm{~S}=0.008 \% \pm 0.006(1 \sigma)$ (Labidi \& Cartigny, 2016) (note this estimate is published on a different CDT scale relative to UMD results that would result in a positive $0.010 \%$ o shift). $\delta^{34} \mathrm{~S}$ of the upper mantle is generally assumed to be negative as a result of core formation (Labidi et al., 2013) but is variable among multiple localities: $-1.28 \pm 0.33 \%$ o $(1 \sigma, n=6$, Labidi et al., 2013) South Atlantic ridge; $-0.89 \pm 0.11 \%$ o $(1 \sigma, n=28$, Labidi et al., 2014)-Pacific-Antarctic ridge; $-0.68 \pm 0.33$ ( $1 \sigma, n=10$, Labidi \& Cartigny, 2016)-Garret transform lavas. At Upolu and Tutuila, representing the Upo Trend $(\mathrm{DM}), \delta^{34} \mathrm{~S}$ is variable and higher than the MORB mantle, ranging from -0.29 to $1.76 \%$ o $( \pm 0.30)$. Whether this represents a source signature or degassing in these three subaerial lavas is unclear. Furthermore, the nature of the depleted component at Upolu and Tutuila is such that it is the least likely to exhibit evidence for recycling. Thus, without unmodified $\delta^{34} \mathrm{~S}$, no clear connection to DM components can be made, although the positive $\delta^{34} \mathrm{~S}$ in these samples may reflect some contribution of exogenous sulfur. We can however argue that the lack of anomalous $\Delta^{33} \mathrm{~S}$ is consistent with the absence of recycled exogenous sulfur, at least as expected for DM components (e.g. Labidi et al., 2014).

\subsubsection{The Vai Trend-the HIMU Component}

The Vai trend is composed of six volcanoes: Tama'i seamount, Soso seamount, Tupito (previously Muli) seamount, Ofu island, Ta'ū island, and Vailulu'u seamount. Radiogenic Pb-isotope data from these volcanoes plot on an array that extends from the Common component to relatively elevated ${ }^{206} \mathrm{~Pb} /{ }^{204} \mathrm{~Pb}$ and ${ }^{208} \mathrm{~Pb} /{ }^{204} \mathrm{~Pb}$ in samples from Vailulu'u that suggests a dilute contribution from a HIMU related component. Sulfur isotope compositions of submarine pillow basalt glasses from the Samoan Vai trend-including Vailulu'u, Ta'ū, and Tupito-were reported in Labidi et al. (2015) and lavas from Vailulu'u and Ofu in Dottin et al. (2020b). The $\mathrm{S}$-isotope data reveal a relationship with radiogenic $\mathrm{Pb}$ and $\mathrm{He}$ that suggests the observed positive $\Delta^{33} \mathrm{~S}$ measured in samples with relatively high ${ }^{206} \mathrm{~Pb} /{ }^{204} \mathrm{~Pb}$ and ${ }^{208} \mathrm{~Pb} /{ }^{204} \mathrm{~Pb}$ from Vailulu'u reflects recycled sulfur associated with a HIMU mantle component. $\Delta^{36} \mathrm{~S}$ data from Dottin et al. (2020b) and Labidi et al. (2015) exhibit slightly anomalous compositions in Vailulu'u basalts that supports the contribution of exogenic $\mathrm{S}$ to the Vai trend volcanoes. Anomalous $\mathrm{S}$ is clearly not well distributed among Vai trend basalts and such may be the result of geochemical zoning of the Samoan mantle plume. In this work, we did not analyze additional samples from the Vai trend (only a reanalysis of AVON3-71-22). Instead, we provide additional insights into the nature and age of the HIMU component within the context of recently published work on HIMU-Mangaia (Dottin et al., 2020a). 
One way to quantify the role of geochemical zoning in the distribution of S-isotope compositions among the Vai trend is through use of measured distance from the Common (C) component in $\mathrm{Pb}$-isotopic space, using a parameter called $\mathrm{D}^{206 / 206 / 208 \mathrm{~Pb}}$ (Jackson et al., 2014), which is expressed as:

$$
\begin{aligned}
& {\left[\left(\left(206 \mathrm{~Pb} /{ }^{204} \mathrm{~Pb} b_{s}-{ }^{206} \mathrm{~Pb} /{ }^{204} \mathrm{~Pb} b_{R}\right) / \mathrm{X}\right)^{2}+\left(\left(207 \mathrm{~Pb} /{ }^{204} \mathrm{~Pb} b_{s}-{ }^{207} \mathrm{~Pb} /{ }^{204} \mathrm{~Pb} b_{R} / Y\right)\right)^{2}\right.} \\
& \left.+\left(\left(208 \mathrm{~Pb} /{ }^{204} \mathrm{~Pb}-{ }^{208} \mathrm{~Pb} /{ }^{204} \mathrm{~Pb} / \mathrm{Z}\right)\right)^{0.5}\right]
\end{aligned}
$$

where $\mathrm{R}=$ reference, $\mathrm{S}=$ sample, and $X, Y$ and $Z$ represent the absolute difference in the measured maximum and minimum values (See Jackson et al., 2014 for further details). In a plot of $\Delta^{33} \mathrm{~S}$ and $\Delta^{36} \mathrm{~S}$ versus $\mathrm{D}^{206 / 207 / 208 \mathrm{~Pb}}$ for Vai trend lavas (Figures $5 \mathrm{a}$ and $5 \mathrm{~b}$ ), $\Delta^{33} \mathrm{~S}$ increases and $\Delta^{36} \mathrm{~S}$ shows an increasing range (with lower extreme values) with increasing distance (higher $\mathrm{D}^{206 / 207 / 208 \mathrm{~Pb}}$ ) from the Common component. This relationship demonstrates sulfur isotope mixing among samples in the Vai trend and shows that increased distance from the Common component toward the HIMU component results in an increasing contribution of recycled sulfur. $\Delta^{33} \mathrm{~S}$ variations are only produced during low-temperature fractionation processes (e.g., Farquhar et al., 2014; Johnston, 2011; Ono et al., 2012). Therefore, the $\Delta^{33} \mathrm{~S}$ composition from HIMU related basalts unambiguously requires a contribution of sulfur that was once surface-derived.

Although the variations are linked to HIMU components, it is important to emphasize that the isotopic composition observed is different from those observed in many HIMU OIB elsewhere, where either negative or no $\Delta^{33} \mathrm{~S}$ variation is observed (e.g., Beaudry et al., 2018; Cabral et al., 2013; Labidi et al., 2013). The HIMU reservoir, if made of ancient subducted oceanic crust that has been devolatilized, may not be intrinsically homogeneous for S-isotopes as there are resolvable isotopic differences observed at present between the lower oceanic crust (dominated by hydrothermal sulfides, $\delta^{34} \mathrm{~S}=+3, \Delta^{33} \mathrm{~S}=0$; Alt, 1995) and the upper altered oceanic crust (dominated by biogenic sulfides, $\delta^{34} \mathrm{~S}=$ variable, $\Delta^{33} \mathrm{~S}$ up to +0.16 , Ono et al., 2012). However, we acknowledge uncertainty in these compositions as the composition of modern oceanic crust may not be a perfect analogue for oceanic crust in deep time. Such diversity in the S-isotope composition of HIMU related materials is reflected by HIMU-influenced MORBs and the Canary Islands showing no resolvable $\Delta^{33} \mathrm{~S}$ variations (Beaudry et al., 2018; Labidi et al., 2014) with rather positive $\delta^{34} \mathrm{~S}$ signatures, whereas HIMU at Mangaia shows both negative and positive $\Delta^{33} \mathrm{~S}$ anomalies with $\delta^{34} \mathrm{~S}$ signatures far lower than the upper mantle (Cabral et al., 2013; Dottin et al., 2020a).

Given the magnitude and direction of the ${ }^{33} \mathrm{~S}$ composition at Vailulu'u, it is possible that there is a link between recycled S at Mangaia and the recycled diluted HIMU component at Samoa. However, the major differences in $\delta^{34} \mathrm{~S}$ of bulk sulfide measurements (down to $\sim-5 \%$ at Mangaia, up to $\sim+2$ at Vailulu'u) and ${ }^{206} \mathrm{~Pb} /{ }^{204} \mathrm{~Pb}$ (nearly 22 at Mangaia, and just $\sim 19.4$ at Vailulu'u) make drawing a direct connection complicated, and in fact, may instead suggest that the Samoan HIMU component is most closely linked to the HIMU components characterized at HIMU influenced MORB (Labidi et al., 2014) and the Canary Islands (Beaudry et al., 2018). We may however be able to draw a connection to their materials through relative age constraints. The relative age of the recycled $\mathrm{S}$ in Samoa can be illustrated through plots of $\Delta^{36} \mathrm{~S}$ versus $\Delta^{33} \mathrm{~S}$. In this space, Archean sulfur typically plots on a slope of -1 , while Proterozoic and Phanerozoic sediments plot on a steeper slope of $\sim 7$ (e.g., Johnston, 2011). Dottin et al. (2020b) show that the data from Vailulu'u plot on a slope of $\sim-7$, which is best attributed to a contribution of post-Archean sulfur at Samoa. Similarly, at Mangaia, bulk S measured in olivine- and clinopyroxene-hosted melt inclusions from pooled magmatic phenocrysts demonstrate a contribution from Proterozoic sulfur (Dottin et al., 2020a). Such commonality in the age of recycled sulfur suggests that at HIMU localities with resolvable $\Delta^{33} \mathrm{~S}$, the recycled $\mathrm{S}$ is usually of post-Archean nature and the crustal protolith with Archean $S$ that is argued to exist on the basis of large negative $\Delta^{33} \mathrm{~S}$ down to -0.35 (Cabral et al., 2013) measured in individual sulfides from Mangaia basalts may not be widely distributed among mantle plumes.

\subsubsection{The Malu Trend-the EM II Component}

An extensive data set from the Malu trend, which is formed by mixing the Samoan Common component with EM II, has been published by Labidi et al. (2015). Additional samples from the Malu trend are presented here with analyses of two additional submarine samples from Malumalu and analyses of two submarine 

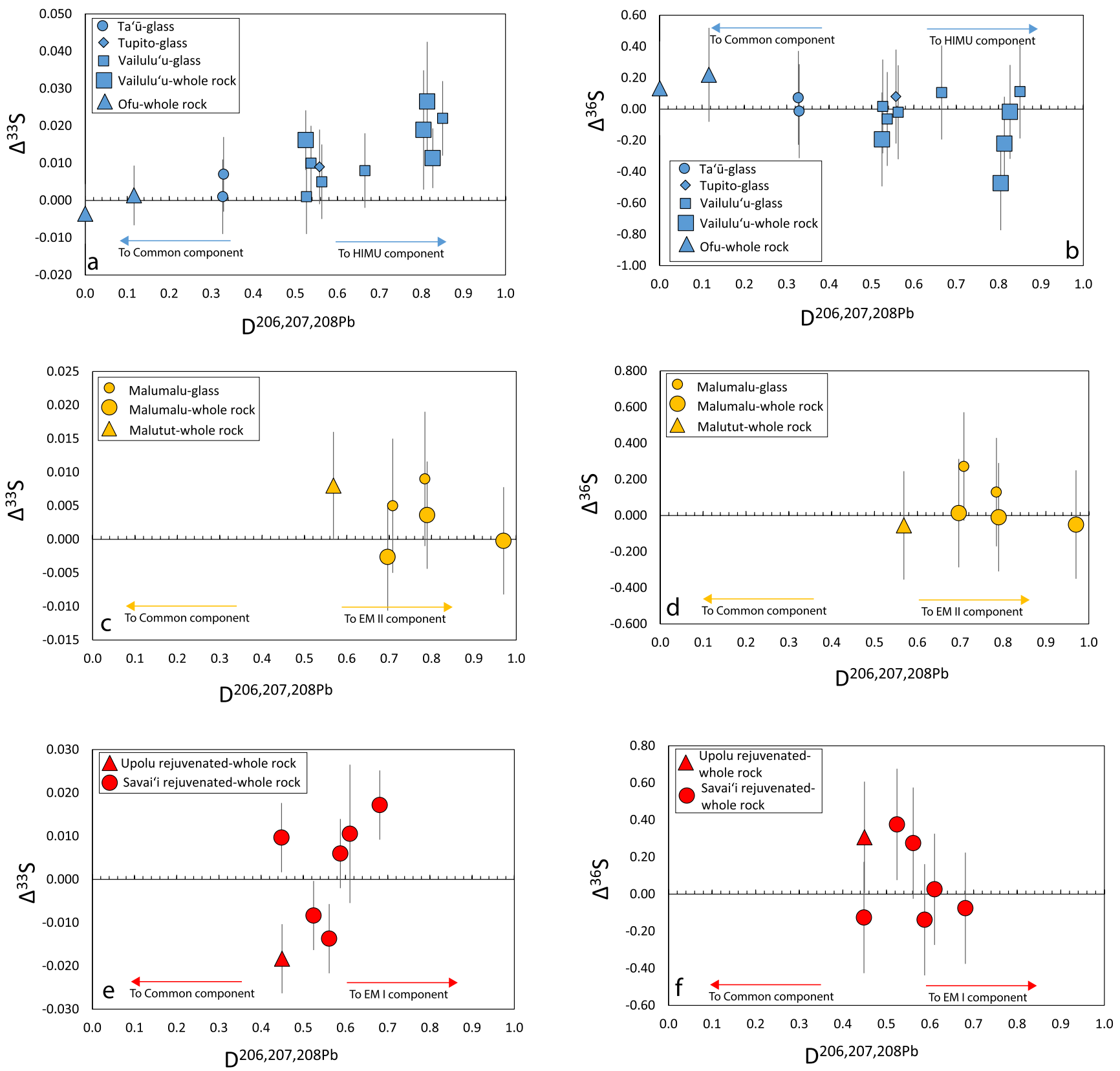

Figure 5. $\Delta^{33} \mathrm{~S}$ and $\Delta^{36} \mathrm{~S}$ versus $\mathrm{D}^{206,207,208 \mathrm{~Pb}}$ for basalts from the Vai trend, Malu trend, and Rejuvenated lavas. $\mathrm{D}^{206,207,208 \mathrm{~Pb}}$ data is from Jackson et al. (2014). S-isotope data are from Dottin et al. (2020b), Labidi et al. (2015) and this study. Data from the Vai trend illustrate an increase in $\Delta^{33} \mathrm{~S}$ and decrease in $\Delta^{36} \mathrm{~S}$ with increasing distance from the Common component. Malu trend basalts outline essentially no trend among the samples. The rejuvenated lavas show a steeper relationship between $\Delta^{33} \mathrm{~S}$ and $\mathrm{D}^{206,207,208 \mathrm{~Pb}}$ than that seen in the Vai trend, and potentially does not converge on a compositional relationship that involves significant influence from the Common component with $\Delta^{33} \mathrm{~S}=0$. Muli seamount is renamed as Tupito. S-isotope data are from reduced sulfur in whole rocks and glasses. For each panel, note the difference in scales on the $Y$-axis which are set to best illustrate the degree of isotopic variation (or lack thereof).

samples from Malutut, another seamount on the Malu volcanic trend. In general, samples from the Malu trend exhibit no resolvable $\Delta^{33} \mathrm{~S}(-0.003$ to 0.010$)$ or $\Delta^{36} \mathrm{~S}(-0.01$ to 0.27$)$ and have positive $\delta^{34} \mathrm{~S}(1.73-2.79)$ (Labidi et al., 2015; Dottin et al., 2020b; this study). ALIA 108-04 is an exception that may have experienced degassing, exhibiting relatively high $\delta^{34} \mathrm{~S}=+4.84 \pm 0.30 \%$ and $\Delta^{33} \mathrm{~S}=0.008 \pm 0.008 \%$.

The $\delta^{34} \mathrm{~S}$ compositions of Samoan basalts from the Malu and Vai trend were previously shown to be correlated with radiogenic ${ }^{87} \mathrm{Sr} /{ }^{86} \mathrm{Sr}$ (Labidi et al., 2015). This relationship is used to define what is termed the "Mantle-Array" that links MORB S-isotope compositions to EM II S-isotope compositions through mixing with a 

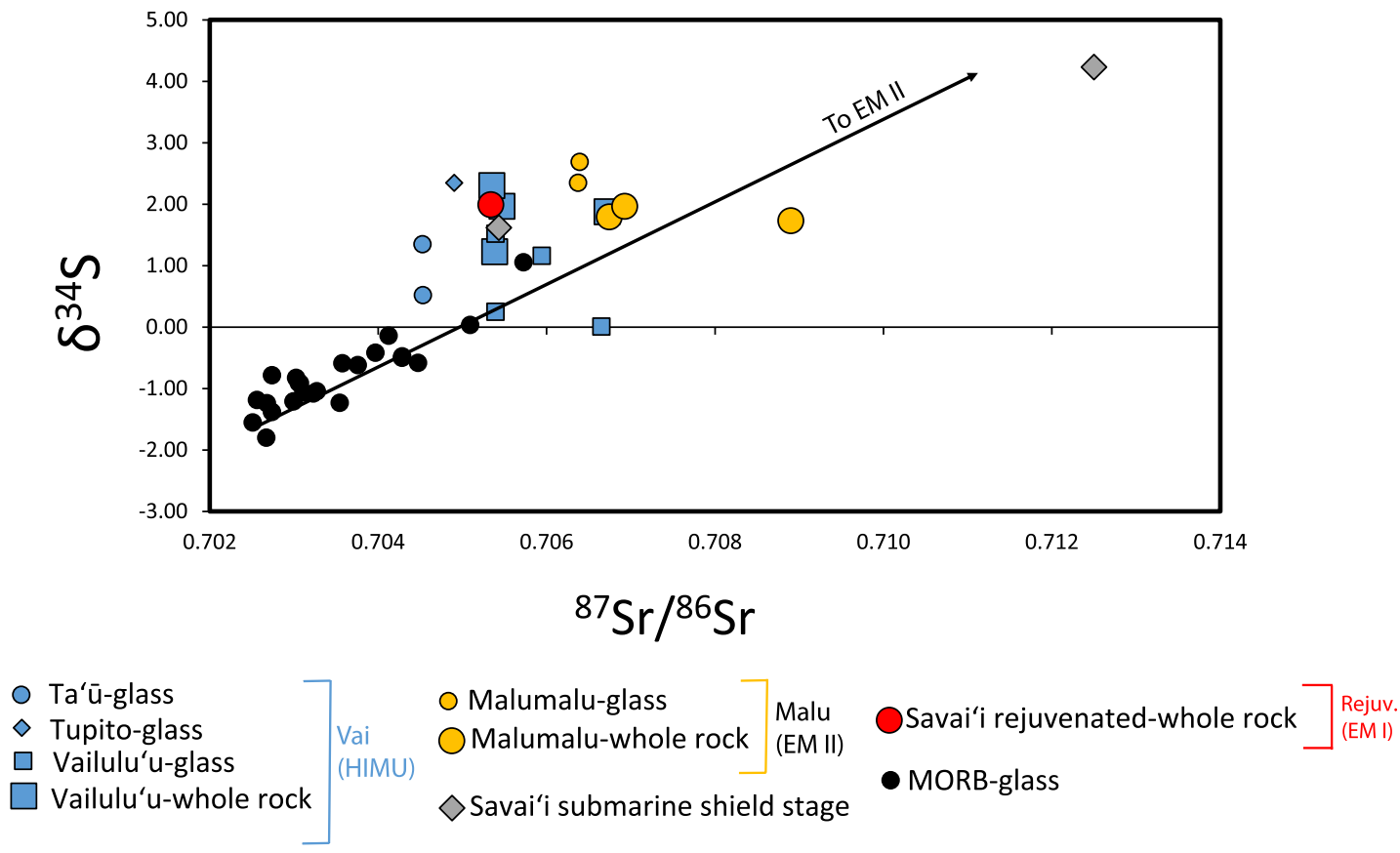

Figure 6. $\delta^{34} \mathrm{~S}$ versus ${ }^{87} \mathrm{Sr} /{ }^{86} \mathrm{Sr}$ for Samoan basalts analyzed in this study and Dottin et al. (2020b) (large symbols represent whole rock analyses) and Labidi et al. (2015) (small symbols represent glasses). MORB data from Labidi et al. (2013). Subaerial basalts are omitted from this plot as they likely host modified $\delta^{34} \mathrm{~S}$. Large symbols from the Vai and Malu trends represent whole rock analyses. Small symbols from the Vai and Malu trends represent glasses. MORB data are from glasses. All other data (rejuvenated lavas and Savaii submarine lavas) are whole rock analyses. All S-isotope data are from extracted sulfide.

Proterozoic sedimentary protolith that hosts a $\delta^{34} \mathrm{~S}$ composition of $+10 \%$ ond a high $\mathrm{S} / \mathrm{Sr}$ ratio of 17 (Labidi et al., 2015). A sample analyzed in this study from Malumalu (AVON3-78-1) has ${ }^{87} \mathrm{Sr} /{ }^{86} \mathrm{Sr}$ that is more radiogenic than samples previously analyzed for S-isotopes and offers an opportunity to test whether the hypothesized crustal protolith is best associated with the material proposed by Labidi et al. (2015). In Figure 6 we plot $\delta^{34} \mathrm{~S}$ versus ${ }^{87} \mathrm{Sr} /{ }^{86} \mathrm{Sr}$ for all submarine samples analyzed in Labidi et al. (2015), Dottin et al. (2020b) and this study (subaerial samples, which have experienced significant degassing and fractionation of $\delta^{34} \mathrm{~S}$, are not plotted in Figure 6). Interestingly, the most positive $\delta^{34} \mathrm{~S}$ is a western Samoan lava dredged at Savai' $\mathrm{i}$ that has ${ }^{87} \mathrm{Sr} /{ }^{86} \mathrm{Sr}$ of 0.7125 , the most extreme high ${ }^{87} \mathrm{Sr} /{ }^{86} \mathrm{Sr}$ EM II lavas characterized for S-isotopes. With the exception of the potentially degassed sample from Malutut (ALIA108-04; see Section 4.1.1), our data appear to be consistent with the model proposed by Labidi et al. (2015), demonstrating that $\delta^{34} \mathrm{~S}$ increases with increasing ${ }^{87} \mathrm{Sr} /{ }^{86} \mathrm{Sr}$.

On a plot of $\Delta^{33}$ S versus $D^{206 / 207 / 208 P b}$, the Malu trend data do not reproduce a relationship like that seen for the Vai trend (Figure $5 \mathrm{c}$ ): $\Delta^{33} \mathrm{~S}$ does not vary at a given $\mathrm{D}^{206 / 207 / 208 \mathrm{~Pb}}$. The lack of any anomalous $\Delta^{33} \mathrm{~S}$ associated with Malu trend basalts confirms previous suggestions that the EM II component has $\Delta^{33} \mathrm{~S}=0$ (Labidi et al., 2015). This value is distinct from those associated with the Vai trend. Furthermore, when we consider the strongly positive $\delta^{34} \mathrm{~S}$ of the Malu-trend basalts (relative to Vai basalts), the S-isotope composition of Malu basalts is unambiguously different from the Vai trend basalts and confirms the Samoan mantle plume is geochemically zoned in terms of recycled components.

\subsubsection{Rejuvenated Lavas-the EM I Component}

Volcanism at Samoa consists of a shield stage that is followed by a period of quiescence ( $\sim 1 \mathrm{Ma}$; Reinhard et al., 2019), and lastly, rejuvenated volcanism. At Samoa, subaerial rejuvenated volcanism occurs on the islands of Savai'i, Upolu, and Tutuila, which are located $>180 \mathrm{~km}$ from the current location of the Samoan mantle plume (which is inferred to lie below the volcanically active Vailulu'u seamount). The source of rejuvenated volcanism at Samoa is not well understood, but has been discussed elsewhere (Konter \& Jackson, 2012; Natland, 1980; Workman et al., 2004; Reinhard et al., 2019). It has been proposed that rejuvenated volcanism at Samoa may be driven by mantle melting from plate flexure of the lithosphere due to 
subduction at the Tonga Trench (Konter \& Jackson, 2012; Natland, 1980). Others have proposed that the Samoan rejuvenated volcanism may be driven by decompression melting of the lithosphere and westwardly swept Samoan plume material due to subduction induced mantle upwelling and toroidal flow around the down going Pacific lithosphere (Strak \& Schellart, 2018). Although at this time we cannot discount the hypothesis of the latter proposal, the hypothesis is difficult to reconcile with the $\mathrm{Pb}$ and S-isotope geochemistry and the current location of the Samoan mantle plume. The EM I component in Samoan rejuvenated lavas is not observed in shield lavas and these materials are erupted $>180 \mathrm{~km}$ away from active plume upwelling. The Pacific lithosphere in the Samoan region was argued to have passed over the Cook-Austral hotspots (which have erupted volcanoes that host EM I signatures), including the EM I Rarotonga hotspot, prior to passage over the Samoan hotspot. The Cook-Austral hotspots may have contributed EM I mantle compositions to the lithosphere, and thus may be the source of the dilute EM I- type mantle signatures of Samoan rejuvenated lavas (Jackson et al., 2014; Konter \& Jackson, 2012). While the presence of a distinct Rarotonga hotspot is currently uncertain (Chauvel et al., 1997; Jackson et al., 2020), this hypothesis provides a possible mechanism for generating the EM I signature in Samoan rejuvenated lavas. Regardless of the origin of EM I, we can use S-isotopes to constrain the source of the materials erupted during Samoan rejuvenated volcanism.

We present data on rejuvenated basalts $(N=6)$ from Samoa that are from the Savai'i, Upolu, and Tutuila Islands and test whether rejuvenated basalts exhibit evidence for a contribution from a sulfur source that is distinct from that associated with the Samoan mantle plume. With the exception of ALIA 116-04 $\left(\delta^{34} \mathrm{~S}=1.99, \Delta^{33} \mathrm{~S}=0.017\right.$, and $\left.\Delta^{36} \mathrm{~S}=-0.076\right)$, a submarine rejuvenated lava, all data on Samoan rejuvenated lavas are from subaerial eruptions and have compositions that range from -0.28 to $1.28,-0.018$ to 0.011 , and -0.14 to 0.38 in $\delta^{34} \mathrm{~S}, \Delta^{33} \mathrm{~S}$, and $\Delta^{36} \mathrm{~S}$ respectively. Upo-7A exhibits the lowest measured $\Delta^{33} \mathrm{~S}$ $(-0.018 \pm 0.008)$ at Samoa to date. Note, as discussed in Section 4.2, the $\delta^{34} \mathrm{~S}$ compositions in the subaerial lavas likely do not reflect that of the parental melt composition due to degassing. Therefore, we focus solely on the $\Delta^{33} \mathrm{~S}$ and $\Delta^{36} \mathrm{~S}$ in this portion of the discussion, but we do note that the single submarine rejuvenated lavas-ALIA 116-04-does have a positive $\delta^{34} \mathrm{~S}$ (1.99) value that suggests the mantle source of Samoan rejuvenated lavas has a positive $\delta^{34} \mathrm{~S}$ composition.

The rejuvenated lavas analyzed in this study do not span a wide range of $D^{206 / 207 / 208 \mathrm{~Pb}}$. Consequently, in plots of $\Delta^{33} \mathrm{~S}$ versus $\mathrm{D}^{206 / 207 / 208 \mathrm{~Pb}}$, the data reveal significant variation of $\Delta^{33} \mathrm{~S}$ within a narrow range of $\mathrm{D}^{206 / 207 / 208 \mathrm{~Pb}}$ $\left(D^{206 / 207 / 208 \mathrm{~Pb}}=0.5\right.$ to 0.7 , Figure $\left.5 \mathrm{e}\right)$. The behavior of $\Delta^{33} \mathrm{~S}$ at a given $\mathrm{D}^{206 / 207 / 208 \mathrm{~Pb}}$ is different from that observed for sulfur associated with the Malu and Vai trends. Like arguments made for the Malu trend and Vai trend data, when mixing with the Common component, any relationships should converge on $\Delta^{33} \mathrm{~S}=0$ at low values of the distance parameter $\left(\mathrm{D}^{206 / 207 / 208 \mathrm{~Pb}}\right)$. Considering $\Delta^{33} \mathrm{~S}$ values measured in rejuvenated lavas do not converge on $\Delta^{33} \mathrm{~S}=0$ as the distance parameter decreases it is possible that the EM I component is isotopically heterogeneous (it has both positive and negative $\Delta^{33} \mathrm{~S}$ ) and is not mixing with a significant amount of the common plume component, if any at all; extreme high ${ }^{3} \mathrm{He} /{ }^{4} \mathrm{He}$ signatures have never been identified in any Samoan rejuvenated lavas, including those with low $\mathrm{D}^{206 / 207 / 208 \mathrm{~Pb}}$ that plot closer to the Common component, consistent with the hypothesis that the rejuvenated lavas may not sample the Samoan plume's high ${ }^{3} \mathrm{He} /{ }^{4} \mathrm{He}$ Common component. As far as we know, the distinctly negative $\Delta^{33} \mathrm{~S}$ value is among the first observed with gas source mass spectrometry in an OIB system (with one observation at Mangaia, Cabral et al., 2013).

Nonetheless, the significant variability in $\Delta^{33} \mathrm{~S}$ among rejuvenated lavas suggests that the origin of the EM I component at Samoa is associated with the incorporation of surface derived materials. Again, this is because $\Delta^{33} \mathrm{~S}$ variations are widespread in sedimentary materials of all ages (e.g. Johnston, 2011) and no $\Delta^{33} \mathrm{~S}$ variations are known to be produced strictly by mantle processes. S with variable $\Delta^{33} \mathrm{~S}$ may be of recycled origin reflecting either biogenic sulfur (which generates relatively small magnitude $\Delta^{33} \mathrm{~S}$ anomalies) or sulfur fractionated through UV-photolysis (which generates large magnitude $\Delta^{33}$ S anomalies). Note, that sulfur derived from UV photolysis would require the observed sulfur to be of Archean age, whereas biogenic sulfur can be of nearly any age (Farquhar et al., 2000, 2007). Our data show rejuvenated lavas are consistent with a post-Archean relationship for $\Delta^{36} \mathrm{~S}$ versus $\Delta^{33} \mathrm{~S}$ (Figure $3 \mathrm{~b}$ ).

Whether the rejuvenated S-isotope composition observed at Upolu is related to the compositions at EM I-flavored Pitcairn remains an outstanding question. At Pitcairn, Delavault et al. (2016) report negative $\Delta^{33} \mathrm{~S}$ 
(down to $-0.85 \%$ \pm 0.13 ) on sulfides from Pitcairn basalts measured via SIMS that are linked to recycled Archean sulfur. In contrast, Discovery lavas, another EM I type hotspot, show $\Delta^{33} \mathrm{~S}$ and $\Delta^{36} \mathrm{~S}$ values that are strictly indistinguishable from $0 \%$ (Labidi et al., 2013), suggesting the EM I S-isotope composition is variable. The negative $\Delta^{33} \mathrm{~S}$ composition in UPO-7A $(-0.018)$ is in the correct direction if trying to link to EM I components at Pitcairn. However, the magnitude of the $\Delta^{33} \mathrm{~S}$ and the measured $\Delta^{36} \mathrm{~S} / \Delta^{33} \mathrm{~S}$ in the Samoan EM I would suggest that here, $\mathrm{S}$ is instead of post-Archean origin. This signature is distinct from Pitcairn, where Archean sulfur is required, and is distinct from Discovery, where $\Delta^{36} \mathrm{~S}-\Delta^{33} \mathrm{~S}$ signatures indistinguishable from average MORB were observed (Labidi et al., 2013).

Our unique $\Delta^{33} \mathrm{~S}$ signatures may potentially be linked to the proposed metasomatized lithospheric mantle beneath the Savai'i and Upolu islands. Hauri et al. (1993) observed extreme carbonatite metasomatism in mantle peridotite xenoliths hosted in Samoan rejuvenated lavas, interpreted to reflect modification of oceanic lithospheric mantle beneath Samoa by carbonatite melts derived from the Samoan plume (Hauri \& Hart, 1994). Note, however that our observed $\Delta^{33} \mathrm{~S}$ variability is different from that observed in mantle xenoliths with EM signatures $\left(\Delta^{33} \mathrm{~S}=0\right.$ to $0.10 \pm 0.08 \%$ (Giuliani et al., 2016)) but may be linked to a separate source of material. Konter and Jackson (2012) argued that prior passage of the oceanic mantle lithosphere over another plume (e.g., Rarotonga) may have imparted a geochemically heterogeneous signature on the lithosphere before it arrived in the Samoan region, separating the rejuvenated lava signature from those erupted during the shield stage associated with the Samoan mantle plume. If Samoan rejuvenated lavas sample the oceanic mantle lithosphere, the metasomatic signatures in the lithosphere beneath Samoa may be reflected in S-isotope compositions. In order to satisfy observations of a distinct S-isotope composition potentially linked to young biogenic sulfides without an influence from Samoan plume material, a post-Archean subduction zone could have delivered biogenic sulfides into the deep mantle (Luguet et al., 2008), where the sulfides were subsequently entrained by an upwelling plume (not necessarily associated with the Samoan plume, but one associated with Rarotonga, for example) and transported to the surface. Subsequently, tectonic stresses associated with the subduction and tearing of the Pacific plate would have contributed to mobilizing this metasomatized lithosphere component, which was melted and contributed to Samoan rejuvenated lavas (Konter \& Jackson, 2012; Reinhard et al., 2019).

\section{Conclusions}

- We present S-isotope compositions on basalts from the Vai Trend, Malu Trend, Upo Trend, and Rejuvenated lavas to test for unique S-isotope compositions associated with each islands' associated geochemical trend. Most data collected, including those with DM-like components, show $\Delta^{33} \mathrm{~S}$ values within uncertainty of the origin $\Delta^{33} \mathrm{~S}=0$. Exceptions are seen in two samples from the Vai trend and two samples from the rejuvenated lavas.

- The different compositional trends appear to have unique S-isotope characteristics that we link to multiple recycled $\mathrm{S}$ sources. Through the use of the $\mathrm{Pb}$ distance parameter, we argue that $\mathrm{S}$ is also geochemically zoned, resulting in unique S-isotope compositions delivered to distinct groups of islands.

- As previously argued in Dottin et al. (2020b), the anomalous $\Delta^{33} \mathrm{~S}$ in the Vai trend is linked to recycled HIMU related sulfur that is mixed with sulfur associated with the Common component $\left(\Delta^{33} \mathrm{~S}=0\right)$. Here we show, that the HIMU component is spatially zoned from the Common component and other recycled materials in the Samoan plume.

- From Malu trend basalts we confirm assertions by Labidi et al. (2015) who argue that the EM II component is heavily influenced by a continental crustal component with strongly positive $\delta^{34} \mathrm{~S}$ (estimated at $10 \%$ ) and $\mathrm{S} / \mathrm{Sr}$ of 17 that define the "Mantle-Array". We show that the array extends out to $\delta^{34} \mathrm{~S}$ values of $\sim 5 \%$ o seen in a Savai'i submarine shield stage lava, that suggests the $\delta^{34} \mathrm{~S}$ is of the EM II component is indeed much more positive than that measured in basalts from Malumalu.

- The data collected on Rejuvenated lavas show both positive and negative $\Delta^{33} \mathrm{~S}$ associated with recycled EM I materials. The $\Delta^{33} \mathrm{~S}$ variability suggests a separate source of $\mathrm{S}$ is contributed during rejuvenated volcanism. We argue that the variability may be linked to subducted EM I components associated with a different slab system that were upwelled and rafted into the Samoan region. 


\section{Data Availability Statement}

Data collected for this manuscript is available in the Digital Repository at the University of Maryland (DRUM) http://hdl.handle.net/1903/27095.

\section{References}

The authors thank Dr. Marcel Regelous for providing Rejuvenated lavas from Savai $i$ i, and Stan Hart and Hubert Staudigel for providing submarine Samoan samples. The authors thank Editor Marie Edmonds for handling this manuscript. The authors also acknowledge Patrick Beaudry and Andrea Giuliani for their careful and thoughtful reviews. M.G. Jackson acknowledges support from NSF EAR-1348082 and OCE-1736984.

Abouchami, W., Hofmann, A. W., Galer, S. J. G., Frey, F. A., Eisele, J., Feigenson, M. (2005). Lead isotopes reveal bilateral asymmetry and vertical continuity in the Hawaiian mantle plume. Nature, 434, 851-856.

Adams, J. V., Jackson, M. G., Spera, F. J., Price, A. A., Byerly, B. L., Seward, G., \& Cottle, J. M. (2021a). Extreme isotopic heterogeneity in Samoan clinopyroxenes constrains sediment recycling. Nature Communications, 12, 1-10. https://doi.org/10.1038/s41467-021-21416-9

Adams, J. V., Spera, F. J., \& Jackson, M. G. (2021b). Trachytic melt inclusions hosted in clinopyroxene offer a glimpse into Samoan EM2-endmember melts. Geochemistry, Geophysics, Geosystems, 22, e2020GC009212. https://doi.org/10.1029/2020gc009212

Alt, J. C. (1995). Sulfur isotopic profile through the oceanic crust: Sulfur mobility and seawater-crustal sulfur exchange during hydrothermal alteration. Geology, 23, 585-588. https://doi.org/10.1130/0091-7613(1995)023<0585:siptto >2.3.co;2

Antonelli, M. A., Kim, S.-T., Peters, M., Labidi, J., Cartigny, P., Walker, R. J., et al. (2014). Early inner solar system origin for anomalous sulfur isotopes in differentiated protoplanets. Proceedings of the National Academy of Sciences of the United States of America, 111, 17749-17754. https://doi.org/10.1073/pnas.1418907111
Beaudry, P., Longpré, M.-A., Economos, R., Wing, B. A., Bui, T. H., \& Stix, J. (2018). Degassing-induced fractionation of multiple sulphur isotopes unveils post-Archaean recycled oceanic crust signal in hotspot lava. Nature Communications, 9, 5093. https://doi.org/10.1038/ s41467-018-07527-w

Burgisser, A., Alletti, M., \& Scaillet, B. (2015). Simulating the behavior of volatiles belonging to the C-O-H-S system in silicate melts under magmatic conditions with the software D-Compress. Computers \& Geosciences, 79, 1-14. https://doi.org/10.1016/j.cageo.2015.03.002

Cabral, R. A., Jackson, M. G., Rose-Koga, E. F., Koga, K. T., Whitehouse, M. J., Antonelli, M. A., et al. (2013). Anomalous sulphur isotopes in plume lavas reveal deep mantle storage of Archaean crust. Nature, 496, 490-493. https://doi.org/10.1038/nature12020

Chauvel, C., McDonough, W., Guille, G., Maury, R., \& Duncan, R. (1997). Contrasting old and young volcanism in Rurutu Island, Austral chain. Chemical Geology, 139, 125-143. https://doi.org/10.1016/s0009-2541(97)00029-6

Delavault, H., Chauvel, C., Thomassot, E., Devey, C. W., \& Dazas, B. (2016). Sulfur and lead isotopic evidence of relic Archean sediments in the Pitcairn mantle plume. Proceedings of the National Academy of Sciences, 113, 12952-12956. https://doi.org/10.1073/pnas.1523805113

Dottin, J. W., III, Labidi, J., Jackson, M. G., Woodhead, J., \& Farquhar, J. (2020a). Isotopic evidence for multiple recycled sulfur reservoirs in the Mangaia mantle plume. Geochemistry, Geophysics, Geosystems, 21, e2020GC009081. https://doi.org/10.1029/2020GC009081

Dottin, J. W., III, Labidi, J., Lekic, V., Jackson, M. G., \& Farquhar, J. (2020b). Sulfur isotope characterization of primordial and recycled sources feeding the Samoan mantle plume. Earth and Planetary Science Letters, 534, 116073. https://doi.org/10.1016/j.epsl.2020.116073

Eiler, J., Cartigny, P., Hofmann, A. E., \& Piasecki, A. (2013). Non-canonical mass laws in equilibrium isotopic fractionations: Evidence from the vapor pressure isotope effect of SF6. Geochimica et Cosmochimica Acta, 107, 205-219. https://doi.org/10.1016/j.gca.2012.12.048

Farley, K. A., Craig, H., Hart, S. R., Hauri, E. H., Oschmann, L. A., \& Whitehead, J. A. (1992). Mantle plumes and mantle sources. Science, 258, 821. https://doi.org/10.1126/science.258.5083.821

Farquhar, J., Bao, H., \& Thiemens, M. (2000). Atmospheric influence of Earth's earliest sulfur cycle. Science, 289, 757-758. https://doi. org/10.1126/science.289.5480.756

Farquhar, J., Peters, M., Johnston, D. T., Strauss, H., Masterson, A., Wiechert, U., \& Kaufman, A. J. (2007). Isotopic evidence for Mesoarchaean anoxia and changing atmospheric sulphur chemistry. Nature, 449, 706-709. https://doi.org/10.1038/nature06202

Farquhar, J., Zerkle, A. L., \& Bekker, A. (2014). Geologic and geochemical constraints on Earth's early atmosphere. In Treatise on geochemistry. (pp. 91-138). Elsevier. https://doi.org/10.1016/b978-0-08-095975-7.01304-8

Fiege, A., Holtz, F., Shimizu, N., Mandeville, C. W., Behrens, H., \& Knipping, J. L. (2014). Sulfur isotope fractionation between fluid and andesitic melt: An experimental study. Geochimica et Cosmochimica Acta, 142, 501-521. https://doi.org/10.1016/j.gca.2014.07.015

Gaillard, F., \& Scaillet, B. (2009). The sulfur content of volcanic gases on Mars. Earth and Planetary Science Letters, 279, 34-43. https://doi. org/10.1016/j.epsl.2008.12.028

Giuliani, A., Fiorentini, M. L., Martin, L. A. J., Farquhar, J., Phillips, D., Griffin, W. L., \& LaFlamme, C. (2016). Sulfur isotope composition of metasomatised mantle xenoliths from the Bultfontein kimberlite (Kimberley, South Africa): Contribution from subducted sediments and the effect of sulfide alteration on S isotope systematics. Earth and Planetary Science Letters, 445, 114-124. https://doi.org/10.1016/j. epsl.2016.04.005

Hanan, B. B., \& Graham, D. W. (1996). Lead and helium isotope evidence from oceanic basalts for a common deep source of mantle plumes. Science, 272, 991-995. https://doi.org/10.1126/science.272.5264.991

Hart, S. R., Hauri, E. H., Oschmann, L. A., \& Whitehead, J. A. (1992). Mantle plumes and entrainment: Isotopic evidence. Science, 256, 517-520. https://doi.org/10.1126/science.256.5056.517

Hauri, E. H., \& Hart, S. R. (1994). Constraints on melt migration from mantle plumes: A trace element study of peridotite xenoliths from Savai'i, Western Samoa. Journal of Geophysical Research, 99, 24301-24321. https://doi.org/10.1029/94jb01553

Hauri, E. H., Shimizu, N., Dieu, J. J., \& Hart, S. R. (1993). Evidence for hotspot-related carbonatite metasomatism in the oceanic upper mantle. Nature, 365, 221-227. https://doi.org/10.1038/365221a0

Hofmann, A.W.(1997). Mantle geochemistry: The message from oceanic volcanism. Nature, 385, 219-229. https://doi.org/10.1038/385219a0

Hofmann, A. W., \& White, W. M. (1982). Mantle plumes from ancient oceanic crust. Earth and Planetary Science Letters, 57, 421-436. https://doi.org/10.1016/0012-821x(82)90161-3

Jackson, M. G., Halldórsson, S. A., Price, A., Kurz, M. D., Konter, J. G., Koppers, A. A. P., \& Day, J. M. D. (2020). Contrasting old and young volcanism from Aitutaki, Cook Islands: Implications for the origins of the Cook-Austral volcanic chain. Journal of Petrology, 61, egaa037. https://doi.org/10.1093/petrology/egaa037

Jackson, M. G., Hart, S. R., Konter, J. G., Koppers, A. A. P., Staudigel, H., Kurz, M. D., et al. (2010). Samoan hot spot track on a "hot spot highway": Implications for mantle plumes and a deep Samoan mantle source. Geochemistry, Geophysics, Geosystems, 11. https://doi. org/10.1029/2010gc003232

Jackson, M. G., Hart, S. R., Konter, J. G., Kurz, M. D., Blusztajn, J., \& Farley, K. A. (2014). Helium and lead isotopes reveal the geochemical geometry of the Samoan plume. Nature, 514, 355-358. https://doi.org/10.1038/nature13794 
Jackson, M. G., Hart, S. R., Koppers, A. A. P., Staudigel, H., Konter, J., Blusztajn, J., et al. (2007a). The return of subducted continental crust in Samoan lavas. Nature, 448, 684-687. https://doi.org/10.1038/nature06048

Jackson, M. G., Kurz, M. D., Hart, S. R., \& Workman, R. K. (2007b). New Samoan lavas from Ofu Island reveal a hemispherically heterogeneous high ${ }^{3} \mathrm{He} /{ }^{4} \mathrm{He}$ mantle. Earth and Planetary Science Letters, 264, 360-374. https://doi.org/10.1016/j.epsl.2007.09.023

Johnston, D. T. (2011). Multiple sulfur isotopes and the evolution of Earth's surface sulfur cycle. Earth-Science Reviews 106, 161-183. https://doi.org/10.1016/j.earscirev.2011.02.003

Konter, J. G., \& Jackson, M. G. (2012). Large volumes of rejuvenated volcanism in Samoa: Evidence supporting a tectonic influence on late-stage volcanism. Geochemistry, Geophysics, Geosystems, 13, Q0AM04. https://doi.org/10.1029/2011gc003974

Koppers, A. A. P., Russell, J. A., Jackson, M. G., Konter, J., Staudigel, H., \& Hart, S. R. (2008). Samoa reinstated as a primary hotspot trail. Geology, 36, 435-438. https://doi.org/10.1130/g24630a.1

Labidi, J., \& Cartigny, P. (2016). Negligible sulfur isotope fractionation during partial melting: Evidence from Garrett transform fault basalts, implications for the late-veneer and the hadean matte. Earth and Planetary Science Letters, 451, 196-207. https://doi.org/10.1016/j. epsl.2016.07.012

Labidi, J., Cartigny, P., Birck, J. L., Assayag, N., \& Bourrand, J. J. (2012). Determination of multiple sulfur isotopes in glasses: A reappraisal of the MORB $\delta 34$ S. Chemical Geology, 334, 189-198. https://doi.org/10.1016/j.chemgeo.2012.10.028

Labidi, J., Cartigny, P., Hamelin, C., Moreira, M., \& Dosso, L. (2014). Sulfur isotope budget (32S, 33S, 34S and 36S) in Pacific-Antarctic ridge basalts: A record of mantle source heterogeneity and hydrothermal sulfide assimilation. Geochimica et Cosmochimica Acta, 133, 47-67. https://doi.org/10.1016/j.gca.2014.02.023

Labidi, J., Cartigny, P., \& Jackson, M. G. (2015). Multiple sulfur isotope composition of oxidized Samoan melts and the implications of a sulfur isotope 'mantle array' in chemical geodynamics. Earth and Planetary Science Letters, 417, 28-39. https://doi.org/10.1016/j. epsl.2015.02.004

Labidi, J., Cartigny, P., \& Moreira, M. (2013). Non-chondritic sulphur isotope composition of the terrestrial mantle. Nature, 501, 208-211. https://doi.org/10.1038/nature12490

Luguet, A., Pearson, D. G., Nowell, G. M., Dreher, S. T., Coggon, J. A., Spetsius, Z. V., \& Parman, S. W. (2008). Enriched Pt-Re-Os isotope systematics in plume lavas explained by metasomatic sulfides. Science, 319, 453-456. https://doi.org/10.1126/science.1149868

Mandeville, C. W., Webster, J. D., Tappen, C., Taylor, B. E., Timbal, A., Sasaki, A., et al. (2009). Stable isotope and petrologic evidence for open-system degassing during the climactic and pre-climactic eruptions of Mt. Mazama, Crater Lake, Oregon. Geochimica et Cosmochimica Acta, 73, 2978-3012. https://doi.org/10.1016/j.gca.2009.01.019

Marini, L., Moretti, R., \& Accornero, M. (2011). Sulfur isotopes in magmatic-hydrothermal systems, melts, and magmas. Reviews in Mineralogy and Geochemistry, 73, 423-492. https://doi.org/10.2138/rmg.2011.73.14

Miyoshi, T., Sakai, H., \& Chiba, H. (1984). Experimental study of sulfur isotope fractionation factors between sulfate and sulfide in high temperature melts. Geochemical Journal, 18, 75-84. https://doi.org/10.2343/geochemj.18.75

Moor, de J. M., Fischer, T. P., Sharp, Z. D., King, P. L., Wilke, M., Botcharnikov, R. E., et al. (2013). Sulfur degassing at Erta Ale (Ethiopia) and Masaya (Nicaragua) volcanoes: Implications for degassing processes and oxygen fugacities of basaltic systems. Geochemistry, Geophysics, Geosystems, 14, 4076-4108. https://doi.org/10.1002/ggge.20255

Moore, J. G., \& Fabbi, B. P. (1971). An estimate of the juvenile sulfur content of basalt. Contributions to Mineralogy and Petrology, 33, 118-127. https://doi.org/10.1007/bf00386110

Mundl, A., Touboul, M., Jackson, M. G., Day, J. M. D., Kurz, M. D., Lekic, V., et al. (2017). Tungsten-182 heterogeneity in modern ocean island basalts. Science, 356, 66-69. https://doi.org/10.1126/science.aal4179

Mundl-Petermeier, A., Walker, R. J., Fischer, R. A., Lekic, V., Jackson, M. G., \& Kurz, M. D. (2020). Anomalous 182 W in high 3He/4He Ocean Island basalts: Fingerprints of Earth's core? Geochimica et Cosmochimica Acta, 271, 194-211. https://doi.org/10.1016/j.gca.2019.12.020 Natland, J. H. (1980). The progression of volcanism in the Samoan linear volcanic chain. American Journal of Science, 280, $709-735$.

Ono, S., Keller, N. S., Rouxel, O., \& Alt, J. C. (2012). Sulfur-33 constraints on the origin of secondary pyrite in altered oceanic basement. Geochimica et Cosmochimica Acta, 87, 323-340. https://doi.org/10.1016/j.gca.2012.04.016

Reinhard, A. A., Jackson, M. G., Blusztajn, J., Koppers, A. A. P., Simms, A. R., \& Konter, J. G. (2019). "Petit Spot” rejuvenated volcanism superimposed on plume-derived samoan shield volcanoes: Evidence From a 645-m drill core from Tutuila Island, American Samoa Geochemistry, Geophysics, Geosystems, 20, 1485-1507. https://doi.org/10.1029/2018gc007985

Strak, V., \& Schellart, W. P. (2018). A subduction and mantle plume origin for Samoan volcanism. Scientific Reports, 8, 1-12. https://doi. org/10.1038/s41598-018-28267-3

Weis, D., Garcia, M. O., Rhodes, J. M., Jellinek, M., \& Scoates, J. S. (2011). Role of the deep mantle in generating the compositional asymmetry of the Hawaiian mantle plume. Nature Geoscience, 4, 831-838. https://doi.org/10.1038/ngeo1328

White, W. M., \& Hofmann, A. W. (1982). Sr and Nd isotope geochemistry of oceanic basalts and mantle evolution. Nature, 296, 821-825. https://doi.org/10.1038/296821a0

Workman, R. K., Eiler, J. M., Hart, S. R., \& Jackson, M. G. (2008). Oxygen isotopes in Samoan lavas: Confirmation of continent recycling. Geology, 36, 551-554. https://doi.org/10.1130/g24558a.1

Workman, R. K., Hart, S. R., Jackson, M., Regelous, M., Farley, K. A., Blusztajn, J., et al. (2004). Recycled metasomatized lithosphere as the origin of the Enriched Mantle II (EM2) end-member: Evidence from the Samoan volcanic chain. Geochemistry, Geophysics, Geosystems, 5, Q04008. https://doi.org/10.1029/2003GC000623

Workman, R. K., Hauri, E., Hart, S. R., Wang, J., \& Blusztajn, J. (2006). Volatile and trace elements in basaltic glasses from Samoa: Implications for water distribution in the mantle. Earth and Planetary Science Letters, 241, 932-951. https://doi.org/10.1016/j.epsl.2005.10.028

Zindler, A., \& Hart, S. R. (1986). Chemical Geodynamics. Annual Review of Earth and Planetary Sciences, 14, 493-571. https://doi. org/10.1146/annurev.earth.14.1.49310.1146/annurev.ea.14.050186.002425 